\title{
O SÍTIO ARQUEOLÓGICO PEDRA DO ALEXANDRE, SERIDÓ, RIO GRANDE DO NORTE Principais resultados de estudos, os sepultamentos e perspectivas para o futuro
}

\section{THE PEDRA DO ALEXANDRE ARCHAEOLOGICAL SITE, SERIDÓ, RIO GRANDE DO NORTE \\ Main Results of Studies, Burials and Perspectives for the Future}

\author{
Sérgio Francisco Serafim Monteiro da Silva ${ }^{1}$ \\ sergiofsmsilva@gmail.com \\ Ana Solari ${ }^{2}$ \\ anasolari74@gmail.com
}

\section{RESUMO}

Este artigo teve por base rever os principais resultados de investigações arqueológicas realizadas entre os anos 1990 e 2020 no sítio Pedra do Alexandre, Seridó, Rio Grande do Norte, com pinturas rupestres e sepultamentos humanos. Durante este processo, foram identificados três problemas de pesquisa: caracterização da tradição dos registros rupestres; a geomorfologia e paleoambiente e a formação do depósito arqueológico; as práticas funerárias e as características bioarqueológicas, com ênfase neste artigo. As prerrogativas para o futuro demandam o uso de tecnologia para análises bioquímicas, radiocarbônicas e isotópicas para a interpretação do processo de povoamento regional, como também novos dados sobre dieta, paleopatologia e reconstituição do paleoambiente.

Palavras chaves: Pedra do Alexandre, pesquisas arqueológicas, sepultamentos humanos.

${ }^{1}$ Departamento de Arqueologia da Universidade Federal de Pernambuco.

${ }^{2}$ Pesquisadora, Programa de Pós-Graduação de Arqueologia da Universidade Federal de Pernambuco. 


\begin{abstract}
This article is intended to review the main results of archaeological investigations carried out between the 1990s and 2020 at the Pedra do Alexandre site, Seridó, Rio Grande do Norte, with cave paintings and human burials. During this process, three research problems were identified: characterization of the tradition of rock records; geomorphology and paleoenvironment and the formation of the archaeological deposit; funerary practices and bioarchaeological characteristics, with emphasis on this article. The prerogatives for the future demand the use of technology for biochemical, radiocarbon and isotopic analyzes for the interpretation of the regional population process, as well as new data on diet, paleopathology and paleoenvironmental reconstitution.
\end{abstract}

Keywords: Pedra do Alexandre, archaeological research, human burial

\title{
ANTECEDENTES DAS PESQUISAS ARQUEOLÓGICAS NO SERIDÓ E NO SÍTIO PRÉ-HISTÓRICO PEDRA DO ALEXANDRE
}

O Rio Grande do Norte apresenta sítios arqueológicos importantes para compreender o fenômeno do povoamento pré-histórico da Região Nordeste do Brasil, especialmente sobre a distribuição espacial e as características geomorfológicas de alguns sítios a céu aberto e abrigos de localidades vizinhas (MARTIN, 1985); características da indústria lítica; aspectos técnicos, simbólicos e representacionais dos registros rupestres (pinturas e gravuras); de processos diagenéticos relacionados com a formação dos depósitos pré-históricos; de formação estratigráfica de contextos arqueológicos; dados sobre as práticas funerárias e caracteres bioantropológicos a partir dos remanescentes ósseos humanos e estudos mais recentes sobre a diagênese e potencial de datação e análise bioquímica desse tipo de vestígio. 
A partir das primeiras prospecções realizadas na área do Seridó, durante a vigência do Projeto Seridó, nos anos 1980, foram incluídos levantamentos de sítios com registros rupestres, coleta de materiais arqueológicos já desenterrados ou recolhidos por habitantes locais. Essas ações, segundo Martin (2000), estavam previstas no Projeto Estruturas arqueológicas dos sítios rupestres das tradições Nordeste e Agreste, $P E, P B$ e $R N$, implementado pelo Núcleo de Estudos Arqueológicos (NEA), da Universidade Federal de Pernambuco e a Fundação Seridó. Nesse contexto de ações prospectivas foi localizado o sítio Pedra do Alexandre.

O sítio arqueológico Pedra do Alexandre, abrigo do Alexandre ou Pedra do Chapéu (MARTIN, 1982, 1995-1996), está localizado em Carnaúba dos Dantas, no sertão do Seridó potiguar, à margem do riacho Ermo, tributário do Rio Carnaúba (de onde o sítio dista cerca de $250 \mathrm{~m}$ ), afluente do rio Seridó, bacia Açu-Piranhas, que desemboca no Atlântico na altura de Macau, no Rio Grande do Norte. Situa-se entre as coordenadas geográficas $6^{\circ} 32^{\prime} 43^{\prime \prime} \mathrm{S}$ e $36^{\circ} 31^{\prime} 10^{\prime \prime} \mathrm{W}$ (RAMOS, 1995), a cerca de 414m de altitude (MARTIN, 1995-1996). Encontra-se em área de depressões interplanálticas, com colinas entre antigos maciços, em meio a um ambiente atual em desertificação no semi-árido do Nordeste (MARTIN, 1994, 1995-1996, 1999).

Apresenta, na porção vertical arenítica, registros rupestres a partir de $3 \mathrm{~m}$ de altura, representativos da Tradição Nordeste e Subtradição Seridó, segundo Ramos (1995). Na mesma microrregião, no rio Seridó e nos seus afluentes da bacia Açu-Piranhas, 
foram prospectados vários sítios pré-históricos com registros rupestres desta Tradição (Figura 1).

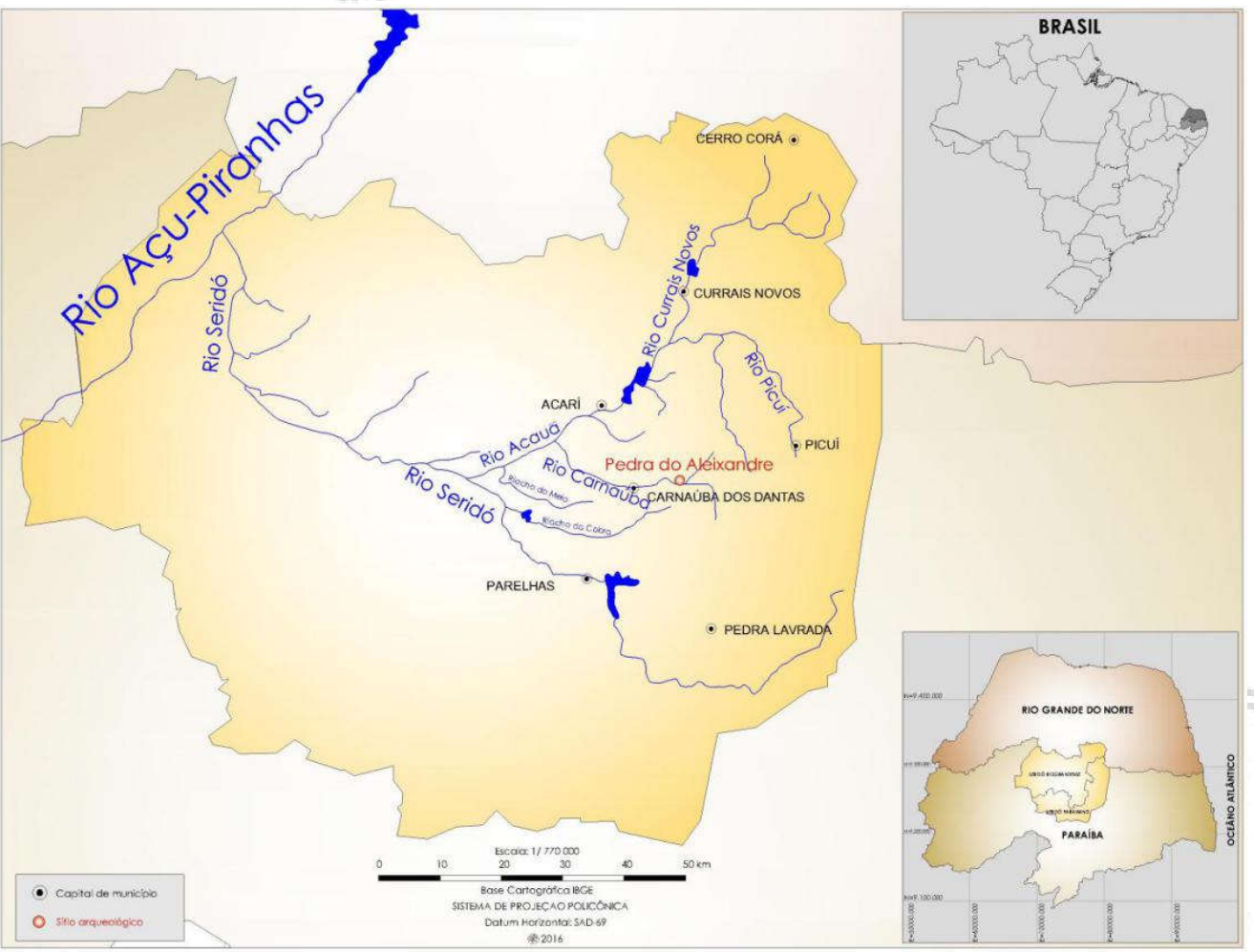

Figura 1. Mapa com a localização do sítio Pedra do Alexandre, na bacia Açu-Piranhas, Rio Grande do Norte, Brasil. Fonte: Núcleo de Estudos Arqueológicos - NEA, UFPE.

Sua porção abrigada é de arenito em decomposição acelerada, com silicatos e micaxisto, o que acarretou o desprendimento de blocos sobre o substrato arqueológico. Estrutura-se em três abrigos próximos entre si, um principal e dois 
menores, formados de silicatos e micaxisto decompostos, com desprendimento de blocos de forma plana e ovalada de tamanhos diversos. O maior abrigo apresenta um teto de cerca de $15 \mathrm{~m}$ de altura, ocupando uma área de $200 \mathrm{~m}^{2}$, com uma plataforma a $2 \mathrm{~m}$ de altura, onde foram produzidos os registros rupestres (pinturas) associados à Tradição Nordeste, Subtradição Seridó (MARTIN, 1994, 1995-96, 1999, 2000).

As camadas arqueológicas do sítio apresentaram dezenas de deposições funerárias, indicando o seu uso como um cemitério pré-histórico. No contexto do Projeto Arqueológico Seridó, foram realizadas 17 campanhas de escavações em campo entre 1990 e 2011 por equipes de arqueólogos e pesquisadores da Universidade Federal de Pernambuco, do Núcleo de Estudos Arqueológicos. Até a última campanha, haviam sido contabilizadas 31 deposições funerárias, entre simples, compostas e perturbadas, com um ou mais indivíduos por cova, apresentando em alguns casos, acompanhamentos funerários, como adornos e ocre vermelho espargido ou em blocos. Os ossos apresentaram diversos tipos de alterações tafonômicas, resultantes de processos culturais e/ou naturais.

O sítio tem sido objeto de pesquisas que se desenvolveram desde décadas de 1990 e 2010 aos dias atuais, gerando estudos importantes para a compreensão do povoamento e modo de vida na região, como também para a geração de novos questionamentos sobre os alcances de determinadas técnicas para a datação absoluta e análises biomoleculares, considerando a severidade dos processos de 
formação do depósito arqueológico e aqueles de natureza diagenética. Os fenômenos de degradação de colágenos e outros indicadores importantes para análises de DNA - ou radiocarbônicas por AMS - minimizam o potencial de análise e interpretação de determinados tipos de vestígios arqueológicos recuperados neste sítio, bem como as remodelações sofridas pela matriz, mediante quedas de blocos do abrigo, ação das águas e modificações antrópicas antigas.

Entre 1990 e 1996, foi escavado cerca de um terço do substrato do sítio, onde não havia blocos caídos e uma porção onde os blocos já estavam sendo movidos para acesso do solo arqueológico. A rocha matriz pôde ser localizada à $1,80 \mathrm{~m}$ de profundidade.

Foram datados 7 sepultamentos das primeiras campanhas e 1 da última, com uso de amostras de carvão, indicando um uso de longa duração do abrigo como locus funerário (MARTIN, 1994, 1999, 2000; MELLO E ALVIM, UCHÔA \& SILVA, 1995-1996). Datações radiocarbônicas de amostras de carvão associado aos ossos humanos nos sepultamentos propiciaram uma reconstrução cronológica preliminar, denotando o tempo de uso funerário deste sítio. As datações foram publicadas em Martin (1994, 1995-1996, 1999), e estão resumidas na Tabela 1. 


\begin{tabular}{|l|l|l|}
\hline Datação (BP) & Laboratório e amostra (carvão) & Sepultamento (número, tipo, número de indivíduos) \\
\hline $2.620 \pm 60$ & CSIC-1061 & Sepultamento 7, primário, 2 subadultos \\
\hline $2.890 \pm 25$ & CSIC-966 & Sepultamento 9, secundário, 1 adulto \\
\hline $2.860 \pm 25$ & CSIC-945 & Sepultamento 9, nível superior \\
\hline $4.160 \pm 70$ & CSIC-1054 & Sepultamento 2, primário, 1 adulto \\
\hline $4.710 \pm 25$ & CSIC-943 & Sepultamento 1, secundário, 1 adulto, 3 subadultos \\
\hline $5.790 \pm 60$ & CSIC-1060 & Sepultamento 6, secundário, 1 subadulto \\
\hline $6010 \pm 60$ & CSIC-1052 & Sepultamento 1, nível inferior \\
\hline $8.280 \pm 30$ & CSIC-965 & Sepultamento 4, primário, 1 adulto \\
\hline $9.400 \pm 35$ & CSIC-967 & Sepultamento 3, secundário, 1 subadulto \\
\hline $9.400 \pm 90$ & CSIC-1051 & Sepultamento 3, nível inferior \\
\hline
\end{tabular}

Tabela 1. Datações do sítio Pedra do Alexandre, Carnaúba dos Dantas (RN), CSIC Consejo Superior de Investigaciones Cientificas, Laboratorio de Física-Química Rocasolano, Madrid.

As datações radiocarbônicas consideradas haviam sido obtidas no Consejo Superior de Investigaciones Científicas (CSIC), Instituto de Física-Química Rocasolano, Laboratorio de Geocronología, Espanha: situavam a presença humana no sítio entre $9.4000 \pm 90$ AP a $2.620 \pm 60$ AP. O material que estava acondicionado no Núcleo de Pesquisas Arqueológicas (NEA) da Universidade Federal de Pernambuco, atualmente se encontra na Reserva Técnica de Materiais Orgânicos (RETEC-Org), junto do Laboratório de Arqueologia Biológica e Forense (LABIFOR) do Departamento de Arqueologia, Centro de Filosofia e Ciências Humanas da UFPE. As datas mais antigas para a ocupação humana no sítio foram consideradas, até 2008 , entre $9.400 \pm 35$ e $9.400 \pm 90 \mathrm{BP}$, obtidas a partir de amostras de carvão associadas aos ossos humanos no sepultamento 3, secundário, com ossos de uma criança de aproximadamente 5 anos de idade. Portanto, as amostras de carvão 
ofereceram datas relativas dos enterros do sítio Pedra do Alexandre. A amostra CSIC 1061, de carvão, estava associada ao sepultamento 7 (A e B), Quadra 2, cota 0,380mm, primário, com dois indivíduos de 4 e 6 anos aproximadamente; conforme Mello e Alvim et al. (1995-1996: 19). A amostra CSIC 1051, carvão, encontravase associada ao sepultamento 3, Quadra 5, cota $0,855 \mathrm{~mm}$, secundário, de criança de aproximadamente 5 anos; conforme Mello e Alvim et al. (1995-1996: 19).

\section{OS ESTUDOS ARQUEOLÓGICOS REALIZADOS A PARTIR DAS ESCAVAÇÕES DO SÍTIO PEDRA DO ALEXANDRE: estudo do ocre, zooarqueologia, registros rupestres, tecnologias, paleoambiente}

As coleções resultantes da pesquisa arqueológica no sítio Pedra do Alexandre resultaram em estudos posteriores realizados no âmbito da pós-graduação e publicados como monografias e artigos científicos. Incluíam análises de corantes das pinturas rupestres e dos sepultamentos humanos, análises zooarqueológicas, da tecnologia lítica e cerâmica, das pinturas rupestres e os estudos paleoambientais e geomorfológicos, buscando compreender a dinâmica sociocultural e os processos formadores do registro arqueológico.

Um método de identificação da origem e composição química dos pigmentos empregados nas pinturas rupestres e encontrados em alguns dos sepultamentos do sítio Pedra do Alexandre foi desenvolvido e aplicado na monografia de Ramos (1992, 1994, 1995-1996). Esta arqueóloga realizou testes químicos e identificou a presença de óxido de ferro (hematita) no pigmento ocre encontrado em forma 
pulverizada ou em blocos com sinais de uso. Trata-se de um dos primeiros estudos pioneiros em arqueometria realizados no sítio.

Sob a perspectiva da zooarqueologia e da tafonomia dos remanescentes faunísticos de Pedra do Alexandre, Queiroz e Cardoso (1995) e Queiroz (2001, 2002) observaram a presença de determinadas espécies por níveis escavados e por datas atribuídas as camadas. Os remanescentes indicaram a presença de animais de pequeno e médio porte, trazidos por outros animais predadores ou pelo homem. Verificou, em amostras, a presença de sinais de cortes, esmagamentos, queima e quebras. Foram observados acompanhamentos funerários sob a forma de apitos e adornos (contas) nos sepultamentos. Portanto, a fauna local era utilizada para a alimentação e fabricação de artefatos, tendo seus vestígios orgânicos sido encontrados desde a camada superficial até as mais profundas, na matriz de solo ou em estruturas de sepultamento. Contas de colar em valvas do gastrópode Olivella $\mathrm{sp.}^{3}$ encontrado na planície costeira, em praias arenosas, foram localizadas entre os acompanhamentos funerários, indicando contatos com grupos do litoral ou mesmo a coleta em áreas litorâneas mais distantes do sertão.

\footnotetext{
${ }^{3}$ As contas desse pequeno gastrópode foram localizadas na Reserva Técnica de Materiais Orgânicos do Departamento de Arqueologia da UFPE em 2018, junto da coleção de Pedra do Alexandre e estão sendo analisadas em uma dissertação de mestrado do Programa de Pós-Graduação de Arqueologia da UFPE sobre adornos pré-históricos da Região Nordeste.
}

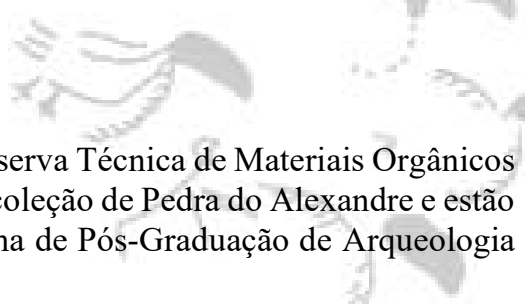


Assim como os sítios Pedra do Chinelo, estudado por Vidal (2002) e Casa de Pedra, circunvizinhos, o sítio Pedra do Alexandre apresentou remanescentes de artefatos cerâmicos. Fontes (2003) estudou o uso e função desses recipientes, não encontrando associação direta dos mesmos com os sepultamentos. Artefatos líticos foram abordados por Martin (1982) e ainda não foram estudados aqueles recuperados no sítio a partir das campanhas de 1990. Os registros rupestres de Pedra do Alexandre foram estudados, direta ou indiretamente no nível regional por Vidal (1995-1996, 2010), Ramos (1992, 1994, 1995-1996), Silva (2003), e Santos Júnior (2005). A conformação paleoambiental e paleogeomorfológica do sítio foram pesquisadas e publicadas por Mutzemberg (2007). Este autor analisou a origem, cronologia e os processos formadores dos extratos sedimentares no sítio, fundamentado pelos princípios metodológicos e técnicos da Geoarqueologia e Arqueologia Ambiental. Fatores naturais e antrópicos contribuíram para a formação do depósito arqueológico conforme se apresenta na atualidade.

\section{O QUE FOI PRODUZIDO SOBRE OS SEPULTAMENTOS E ESQUELETOS HUMANOS DE PEDRA DO ALEXANDRE}

Os primeiros resultados gerais ou sobre temas específicos relacionados as pesquisas arqueológicas sobre os sepultamentos humanos escavados no sítio Pedra do Alexandre foram publicados em Martin (1994, 1995-1996, 1999), Ramos (1995), Mello e Alvim, Uchôa e Silva (1995-1996), Santos (1997), Castro (2009), Farias 
(2013), Santos (2010, 2014, 2020), Santos (2016), Solari et al. (2015), Solari et al. (2016a), Solari et al. (2016b), Sullasi et al. (2017), Solari et al. (2018), entre outros ${ }^{4}$.

Os primeiros estudos sobre o sítio Pedra do Alexandre, com foco parcial nas práticas funerárias devem-se a Martin (1994, 1995-1996, 1995). São descritos os resultados da primeira fase das escavações arqueológicas no sítio e as primeiras interpretações e hipóteses sobre as práticas funerárias no abrigo.

Silva (2004) e Castro (2009) desenvolveram estudos na linhagem da Arqueologia funerária. A primeira autora associou dados arqueológicos com etnográficos para estabelecer e comparar padrões funerários ou perfis de práticas funerárias para a região Nordeste do Brasil. Tratava-se de enterramentos em covas, estruturadas por pedras ou em nichos entre rochas do abrigo, contendo entre 1 a 4 indivíduos, pelo menos. Em poucas deposições melhor preservadas foi possível a identificação de dados sobre a posição do corpo e disposição dos membros. Nesses casos, predominou a posição em decúbito lateral. Silva (2004) observou que perturbações naturais e sucessão de aberturas de covas dificultaram a identificação das formas e profundidades das covas. Ainda, a autora considerou a presença de acompanhamentos funerários em sua pesquisa, mas não identificou associações dos mesmos com o sexo ou a idade dos indivíduos.

\footnotetext{
${ }^{4}$ Aqui não foram incluídos alguns trabalhos de conclusão de curso de graduação.
} 
Os marcadores identitários coletivos dentro de estruturas funerárias nos sítios Furna do Estrago, Pedra do Alexandre, Justino, São José II, Toca do serrote do Tenente Luiz e Toca da Baixa dos Caboclos foram estudados comparativamente por Castro (2009). A cultura material representa, simboliza uma parte da identidade coletiva e esta é 'transmitida' dentro da memória coletiva. Em Pedra do Alexandre, a quase ausência de recorrências associadas a uma possível permanência de identidade coletiva foi observada pela autora. Nesse rol, incluem-se as deposições secundárias de crianças e as estruturas de pedra ou nichos como delimitadores e caracterizadores das deposições.

No âmbito da arqueologia experimental e da Tafonomia arqueológica, Farias (2013) procurou analisar como se caracteriza o processo de conservação e destruição óssea no sítio Pedra do Alexandre. A partir de experimentos com diáfises ósseas de Bos sp. e mandíbulas de Sus sp., o autor simulou ambientes de inumação e de pigmentação com ocre vermelho nos ossos com amostras de solos de três camadas estratigráficas do sítio. Os processos de degradação seguiram-se sem diferenças nas três amostras de solos. Mais tarde, os estudos experimentais de Santos (2016) e Sullasi et al. (2017) representaram um marco importante nos estudos de tafonomia arqueológica, com ênfase na análise da diagênese óssea encontrada em amostras de esqueletos dos sepultamentos do Pedra do Alexandre. A partir destes estudos, torna-se possível triar amostras potenciais para análises biomoleculares e para datação de ossos e dentes neste sítio; e traçar parâmetros mais precisos sobre os processos formativos do registro arqueológico. 
Um primeiro estudo de morfologia dos remanescentes ósseos humanos recuperados até 1996 em Pedra do Alexandre originou o artigo de Mello e Alvim et al. (1995-1996). Este estudo osteobiográfico da população indicou a prevalência da dolicocrania; a presença de hiperosteose, osteoporose e osteoartrose, desgaste dentário e cáries. Segundo as autoras, os resultados das análises osteométricas e osteoscópicas dos remanescentes humanos não possibilitaram caracterizar um único padrão morfológico para a população.

Conforme o artigo de Mello e Alvim et al. (1995-1996), foram considerados parcialmente 24 indivíduos, de um total de 27 esqueletos. Entre os sepultamentos considerados nas análises osteométricas e osteoscópicas estão o 1 (esqueleto A), 2 , 3, 4, 7 (esqueleto B), 8, 9, 10, 15 (esqueletos A e B). A partir da análise dos dados foram apresentadas características sobre a morfoscopia e a morfometria dos ossos, em consonância com a metodologia adotada. O Quadro 1 sintetiza os resultados obtidos: 


\begin{tabular}{|c|c|c|}
\hline $\begin{array}{l}\text { Região do } \\
\text { esqueleto }\end{array}$ & Caracteres morfoscópicos & Caracteres morfométricos \\
\hline Crânio & $\begin{array}{l}\text { Alongados }(77,77 \%) \text {, medianamente alongados (11,11\%), } \\
\text { arredondados ( } 11,11 \%) \text {; inserções musculares marcadas; } \\
\text { fronte média e larga, inclinada; arcos superciliares pouco } \\
\text { desenvolvidos; glabela moderadamente desenvolvida; linhas } \\
\text { temporais entre pouco e moderadamente desenvolvidas; } \\
\text { mento em forma piramidal e de estrela (formas } 2 \text { e } 3 \text {, Schulz, } \\
\text { 1933); extroversão do ângulo mandibular (forma 3, Keiter); } \\
\text { base da mandíbula com formas } 2 \text { e } 3 \text { de Keiter (1929); ângulo } \\
\text { mandibular fechado; concavidade regular da incisura } \\
\text { mandibular (forma 1, Schulz); curvatura fraca da borda } \\
\text { anterior do ramo mandibular; linha milohioidea muito } \\
\text { desenvolvida; inserção do músculo pterigoideo medial muito } \\
\text { desenvolvida e em crista; fossas submandibular e digástrica } \\
\text { muito marcadas; vértex situado atrás do bregma; sutura } \\
\text { escamosa de forma arqueada; bordas orbitais rombas; órbitas } \\
\text { quadrangulares; zigomáticos moderadamente desenvolvidos; } \\
\text { face moderadamente protusa; arco alveolar de forma } \\
\text { parabólica; sutura palatina transversa com concavidade } \\
\text { anterior; processo mastoideo moderadamente desenvolvido; } \\
\text { longo eixo do ramo mandibular; forame mentoniano abaixo } \\
\text { do primeiro premolar; parietais e occipitais curvos; forame } \\
\text { magno moderadamente largo }\end{array}$ & 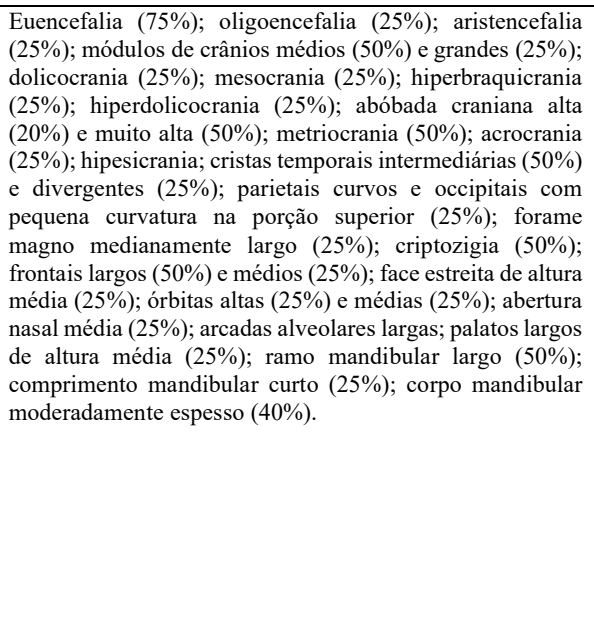 \\
\hline Pós-crânio & $\begin{array}{l}\text { Forame do olecrano; tuberosidade deltoidea desenvolvida; } \\
\text { forame esternal; diáfise placnêmica da tíbia; tálus com faceta } \\
\text { medial de acocoramento; calcâneo com faceta articular talar } \\
\text { dupla; úmero euribráquico; assimetria de desenvolvimento } \\
\text { no rádio; vértebras pequenas; incisura isquiática maior } \\
\text { fechada; forame obturado oval; acetábulo desenvolvido; } \\
\text { fossa hipotrocanteriana de pouco desenvolvida a marcada; } \\
\text { tubérculo quadradado do fêmur desenvolvido; crista } \\
\text { hipotrocanteriana pouco desenvolvida; seç̧ão elíptica do } \\
\text { fêmur; saliência da linha áspera pouco marcada; patela } \\
\text { codiforme; face lateral da tíbia côncava; faceta suplementar } \\
\text { na epífise distal da tíbia (acocoramento); acrômios } \\
\text { desenvolvidos; acrômios falciformes; sacro com base } \\
\text { hipobasal; terceiro trocânter; espinha escapular de forma } 2 \text { de } \\
\text { Vallois (melano-africano); úmero platibráquico; ulna com } \\
\text { bordas articulares extrovertidas (ação de arremesso); bordas } \\
\text { do olecrano e incisuras troclear e radial extrovertidas; } \\
\text { vértebra sacral } 1 \text { hipobasal; fossas hipotrocantéricas } \\
\text { marcadas; cavidade glenóide da escápula piriforme. }\end{array}$ & $\begin{array}{l}\text { Úmero curibráquico }(40 \%) \text {, platibráquico }(40 \%) \text {, com } \\
\text { cabeça elíptica }(100 \%) \text {, variando de muito robustos }(20 \%) \\
\text { a gráceis }(20 \%) \text {; ulnas platolênicas }(80 \%) \text { e eurolênicas } \\
(20 \%) \text {; rádio muito robusto }(25 \%) \text {; fêmures gráceis }(25 \%) \text {, } \\
\text { robustos }(25 \%) \text { e plactimétricos }(100 \%) \text {, colo } \\
\text { moderadamente largo no sentido sagital }(100 \%) \text { cabeça do } \\
\text { fêmur de forma redonda a achatada anteroposteriormente; } \\
\text { fíbulas robustas a pouco robustas e com maiores e menores } \\
\text { diâmetros diafisários iguais; tíbias mesocnêmicas, } \\
\text { euricnêmicas e platicnêmicas; tálus largos ou altos e de } \\
\text { pequena altura ou larguras moderadas. }\end{array}$ \\
\hline \multicolumn{2}{|c|}{ Região do esqueleto } & 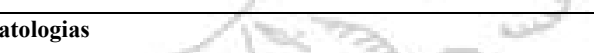 \\
\hline \multicolumn{2}{|l|}{ Crânio } & co e forma ativa); osteoporose puntiforme no frontal (50\%), \\
\hline
\end{tabular}




\begin{tabular}{|l|l|l|}
\hline Pós-crânio & Osteoartrose nas vértebras lombares ou toda a coluna vertebral \\
\hline Região do esqueleto & Caracteres dimórficos para o sexo feminino & Caracteres dimórficos para o sexo masculino \\
\hline Crânio & $\begin{array}{l}\text { Eurimetópicos, mesoconcos, impressões musculares } \\
\text { menos marcadas }\end{array}$ & $\begin{array}{l}\text { Frontal inclinado, órbitas altas, criptozigia, cristas } \\
\text { temporais divergentes e intermediárias, palatos } \\
\text { largos, corpo da mandíbula espesso, impressões } \\
\text { musculares bem marcadas }\end{array}$ \\
\hline Pós-crânio & $\begin{array}{l}\text { Impressões musculares menos marcadas; fíbulas } \\
\text { pouco robustas, com menor diâmetro do meio muito } \\
\text { reduzido; tíbias gráceis e euricnêmicas; úmeros } \\
\text { gráceis }\end{array}$ & $\begin{array}{l}\text { Ossos maiores, impressões musculares bem } \\
\text { marcadas }\end{array}$ \\
\hline \multicolumn{1}{|c|}{ Caracteres dentários } \\
\hline $\begin{array}{l}\text { Incisivos centrais em forma de pá dupla; hipoplasia do esmalte; nanismo dos terceiros molares superiores; inclusão de terceiro molar inferior } \\
\text { direito; módulo cingular nos incisivos laterais superiores; assimetria entre incisivos laterais superiores; desgaste dentário (100\%); desgaste } \\
\text { moderado nos dentes superiores, formando um sulco central (similar a casos registrados em Lagoa Santa); desgaste acentuado nos primeiros } \\
\text { e segundos pré-molares superiores; desgaste nas faces incisais superiores de origem cultural; desgaste dos incisivos laterais inferiores de } \\
\text { origem cultural; cárie (40\%), com cárie de colo em segundo molar superior direito, segundo molar inferior direito, entre os incisivos centrais } \\
\text { superiores, face labial do terceiro molar inferior, face lingual do segundo molar superior direito; apinhamento dentário nos caninos superiores, } \\
\text { incisivos, pré-molar e canino direito; terceiro molar inferior direito parcialmente incluso. }\end{array}$
\end{tabular}

Quadro 1. Resumo dos diagnósticos morfoscópicos, morfométricos, patologias, caracteres dimórficos 131
para sexo e caracteres dentários dos esqueletos de Pedra do Alexandre (adaptado de Mello e Alvim et al., 131 1995-1996)

Os dados apresentados no Quadro 1 foram obtidos a partir da análise de 10 dos 27 indivíduos escavados até 1996 no sítio Pedra do Alexandre e consideraram as seguintes unidades ou conjuntos ósseos (Gráfico 1):

$$
\begin{aligned}
& \text { Número de elementos ósseos analisados - Pedra do Alexandre } \\
& \text { (1996) - } \mathrm{n}=10 \text { indivíduos }
\end{aligned}
$$

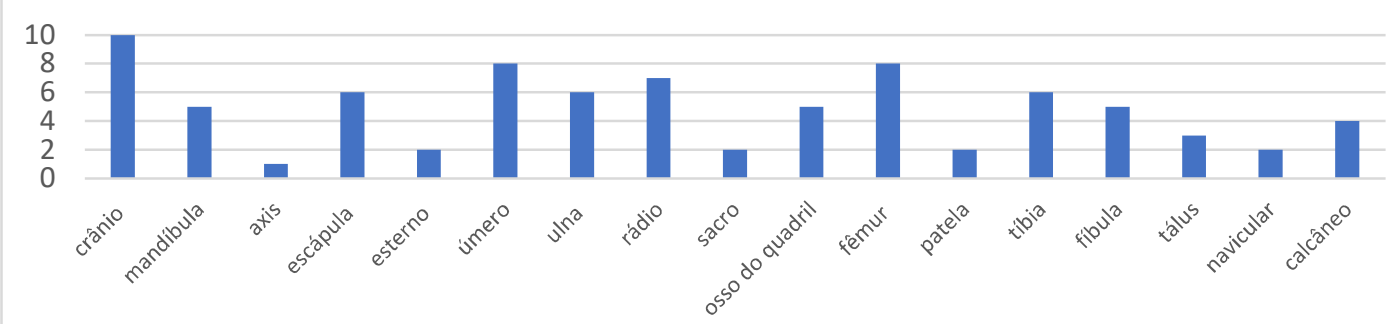

Gráfico 1. Ossos e conjuntos de ossos analisados no artigo de Mello e Alvim et al. (19951996) sobre a osteobiografia de Pedra do Alexandre. 
O Gráfico 1 apresenta a disponibilidade de elementos ósseos para a caracterização osteobiográfica dos esqueletos do sítio Pedra do Alexandre que estão sob a guarda do Departamento de Arqueologia da UFPE. Até 1996 haviam sido escavados 19 sepultamentos humanos, dos quais os sepultamentos 1, 7 e 15 apresentaram mais de um indivíduo e os demais eram simples. Entre os 19 sepultamentos, 6 foram classificados como primários e 13 como secundários. As deposições funerárias simples ou compostas estavam distribuídas entre as cotas de $0,250 \mathrm{~mm}$ a $1,830 \mathrm{~mm}$. Foram identificados (em $\mathrm{n}=24), 2$ indivíduos femininos, 6 indivíduos masculinos, 12 crianças, 2 fetos e 2 indivíduos até então não classificados quanto as categorias de sexo e idade. Nesta publicação o número de indivíduos entre 0 a 21 anos de idade alcançou $70,60 \%$ e os adultos acima de 21 anos, 29,40\%, indicando um número significativo de subadultos no contexto arqueológico.

Uma característica observada por Mello e Alvim et al. (1995-1996: 31) nos remanescentes ósseos humanos de Pedra do Alexandre foi encontrada em esqueletos da região de Lagoa Santa: “(...) desgaste moderado nos dentes superiores formando um sulco central como se os dentes estivessem divididos ao meio, similar aos casos registrados para o 'Homem de Lagoa Santa' (...)". Crânios altos e alongados, bem como a espinha escapular de tipo "melano-africano" também podem estar associados aos grupos de Lagoa Santa. Entretanto, poucos são os dados métricos que podem, efetivamente, ser comparados. As variações individuais mostraram-se preponderantes, considerando o número reduzido e muito fragmentário dos esqueletos escavados no Pedra do Alexandre. 
No mesmo período da publicação de Mello e Alvim (1995-1996), Ramos (1995) já havia apresentado os resultados das suas análises sobre os pigmentos encontrados no sítio, incluindo os ocres das sepulturas. Santos (1997) procurou realizar uma análise paleopatológica dos remanescentes humanos, enfocando o uso de raio $\mathrm{X}$ e preceitos da diagnose médica histopatológica para caracterizar remodelações resultantes de doenças, traumas e anomalias. Observou 11 indivíduos do sítio Pedra do Alexandre. Nota-se, neste estudo, que a distinção entre fraturas antemortem e quebras postmortem ofereceram dificuldades para a sua distinção ou diagnose. $\mathrm{O}$ autor descreveu 14 sepultamentos, conforme o Quadro 3:

\begin{tabular}{|c|c|c|c|c|c|}
\hline Sepultamento & Tipo & Contexto da cova & Posição do corpo & Sexo & Idade \\
\hline 1 & Secundário & $\begin{array}{lll}\text { Fossa rodeada por } \\
\text { pedras }\end{array}$ & - & $\begin{array}{l}\text { masculino } \\
- \\
-\end{array}$ & $\begin{array}{l} \pm 22 \text { anos (adulto) } \\
\pm \quad 11 \quad \text { anos } \\
\text { (criança) } \\
9 \text { meses } \pm 3 \text { m3ses } \\
\text { (feto) }\end{array}$ \\
\hline 2 & Primário & $\begin{array}{l}\text { Coberto por pedras; } \\
\text { pedra sobre o tórax }\end{array}$ & Decúbito lateral & masculino & \pm 18 anos (adulto) \\
\hline 3 & Secundário & $\begin{array}{l}\text { Junto à rocha, entre } \\
\text { conjunto de pedras }\end{array}$ & - & - & $\begin{array}{l}5 \text { anos } \pm 16 \text { meses } \\
\text { (criança) }\end{array}$ \\
\hline 4 & Primário & $\begin{array}{ll}\text { Inumação coberta por } \\
\text { pedras acima dos } \\
\text { membros inferiores }\end{array}$ & - & feminino & $\begin{array}{l}30 \text { a } 35 \text { anos } \\
\text { (adulto) }\end{array}$ \\
\hline 5 & Secundário & \begin{tabular}{lcll} 
Fossa & de & \multicolumn{2}{l}{ inumação } \\
cavada & ao & lado de \\
pedras & & & \\
\end{tabular} & - & - & $\begin{array}{l} \pm 2 \text { anos } \pm 6 \text { meses } \\
\text { (criança) }\end{array}$ \\
\hline 6 & Secundário & $\begin{array}{l}\text { (ossos desarticulados de } \\
\text { um esqueleto) }\end{array}$ & - & - & - \\
\hline 7 & Primário & Ladeado por pedras & 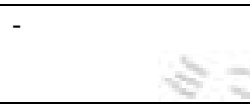 & - & $\begin{array}{l}7 \text { anos (criança) } \\
+\quad 6 \quad \text { meses } \\
\text { (criança) }\end{array}$ \\
\hline 8 & Primário & $\begin{array}{l}\text { Circundado por pedras } \\
\text { em formação circular }\end{array}$ & $\begin{array}{l}\text { (“ossos friáveis, } \\
\text { dentes esfarelados, } \\
\text { sem externo") }\end{array}$ & & $\begin{array}{ll}+12 & 12 \\
(\text { criança) } & \end{array}$ \\
\hline 9 & Secundário & $\begin{array}{l}\text { Não está circundado por } \\
\text { pedras }\end{array}$ & \begin{tabular}{lr}
\multicolumn{2}{l}{ Ossos } \\
\multicolumn{2}{l}{ desarticulados; } \\
ossos & longos \\
dispostos & na \\
\end{tabular} & masculino & \pm 22 anos (adulto) \\
\hline
\end{tabular}




\begin{tabular}{|c|c|c|c|c|c|}
\hline Sepultamento & Tipo & Contexto da cova & Posição do corpo & Sexo & Idade \\
\hline 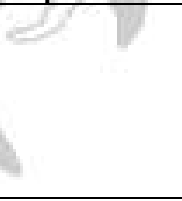 & & & $\begin{array}{l}\text { vertical; abaixo } \\
\text { estão as costelas, } \\
\text { vértebras, ilíaco e } \\
\text { sacro; crânio serve } \\
\text { de apoio para os } \\
\text { ossos longos } \\
\end{array}$ & & \\
\hline 10 & Primário & Apresenta cova & $\begin{array}{l}\text { Decúbito lateral } \\
\text { com mão esquerda } \\
\text { abaixo da face, mão } \\
\text { direita perto dos } \\
\text { olhos; alguns ossos } \\
\text { desarticulados e } \\
\text { fragmentados }\end{array}$ & feminino & \pm 55 anos (adulto) \\
\hline 11 & Primário & - & $\begin{array}{lr}\text { Ossos friáveis } & \text { e } \\
\text { fragmentados, } & \\
\text { falanges } & \text { em } \\
\text { posição anatômica } \\
\text { (?). Ossos r de } \\
\text { origem } & \text { não } \\
\text { identificada } & \\
\end{array}$ & - & - \\
\hline 12 & Secundário & $\begin{array}{l}\text { Tem a estrutura de cova; } \\
\text { mancha que sugere } \\
\text { restos de cremação }\end{array}$ & Restos de esqueleto & - & - \\
\hline 13 & Primário & $\begin{array}{l}\text { Ladeado por estruturas } \\
\text { de pedra }\end{array}$ & $\begin{array}{l}\text { Fragmentos do } \\
\text { crânio e membro }\end{array}$ & - & (adulto) \\
\hline 14 & Secundário & Tem estrutura de cova & $\begin{array}{lr}\begin{array}{l}\text { (esqueleto } \\
\text { coloração }\end{array} & \text { com } \\
\text { escura quis } \\
\text { restantes) }\end{array}$ & - & - \\
\hline
\end{tabular}

Quadro 3. Descrição dos 16 esqueletos do sítio Pedra do Alexandre quanto ao número, tipo, contexto da cova, posição do corpo, sexo e idade (adaptado da descrição do texto de Santos, 1997: 168-9).

Entre os 16 esqueletos descritos inicialmente por Santos (1997), teriam sido analisados 10 esqueletos. Para fins de análises anatomopatológicas por inspeção macroscópica consideraram peças anatômicas dos esqueletos dos sepultamentos 1 (A e B), 2, 3, 4, 5, 6, 7 (A e B), 8, 9, 10, 11, 12, 13 e 14. Os procedimentos visaram, segundo este autor, a estimativa de idade, estatura e atribuição de sexo. Para um estudo detalhado do aspecto osteológico, radiológico e histológico, foram escolhidos os esqueletos incompletos 1(A e B), 2, 4, 7 (A e B), 9 e 10. Para Santos 
(1997: 173), sepultamento ainda é sinônimo de esqueleto. Foram propostas descrições perinecroscópicas e osteológicas (descrição dos fragmentos ósseos quanto a sua identificação e preservação). O Quadro 4 apresenta uma relação de fragmentos analisados e descritos por Santos (1997):

\begin{tabular}{|c|c|}
\hline $\begin{array}{l}\text { Sepultamento } \\
\text { (indivíduo) }\end{array}$ & Fragmentos ósseos analisados \\
\hline $1(\mathrm{~A})$ & $\begin{array}{l}\text { Ossos do neurocrânio (sutura escamosa fechada); fragmento de mandíbula com } 6 \text { dentes articulados; } \\
4 \text { fragmentos de vértebras ( } 2 \text { cervicais, } 1 \text { toráxica, } 1 \text { lombar); } 2 \text { fragmentos do úmero direito (terços } \\
\text { proximal e distal); rádio direito; terço proximal da ulna esquerda; } 2 \text { fragmentos de ossos do quadril; } \\
\text { fragmento de sacro; fragmento de terço proximal e médio do fêmur direito; terço distal do fêmur } \\
\text { esquerdo (radiografia descrita); fragmento do terço proximal da tíbia direita (radiografia descrita); } \\
\text { fragmento dos terços distal e médio de fíbula; esterno. As origens e inserções musculares indicaram } \\
\text { frequência de uso dos músculos do ombro e cotovelo, bíceps braquial, músculo quadrado pronador e } \\
\text { redondo pronador umeral e ulnar. Foram usados fragmento de tíbia e fêmur para exame histológico } \\
\text { (cortes teciduais de aspecto basolítico amorfo de aspecto calcário) }\end{array}$ \\
\hline $1(\mathrm{~B})$ & $\begin{array}{l}\text { Ossos do neurocrânio reconstituídos; } 3 \text { fragmentos de vértebras torácicas; fragmento do terço } \\
\text { proximal do úmero; fragmento distal de úmero; fragmento de terço proximal de ulna; fragmento de } \\
\text { terço distal de fêmur direito; fragmento de tíbia esquerda. Foram registradas fraturas no úmero e ulna } \\
\text { sem remodelação óssea (fraturas de ocorrência mais frequente na faixa etária do indivíduo } \\
\text { examinado?). Foram radiografados fragmentos ósseos não especificados. Foram usados fragmento de } \\
\text { tíbia, fêmur e crânio para exame histológico (cortes teciduais de aspecto basolítico amorfo de aspecto } \\
\text { calcário) }\end{array}$ \\
\hline 2 & $\begin{array}{l}\text { Ossos do crânio e face (reconstituídos e radiografia descrita); úmero esquerdo; fragmento do rádio } \\
\text { esquerdo; fragmento de osso do quadril; fêmur direito; fêmur esquerdo (fragmentos); terço proximal } \\
\text { e médio da tíbia esquerda. Apresenta lesões inespecíficas, mas sugestivas de hiperosteose porótica na } \\
\text { órbita direita, glabela, parte anterior do parietal e do occipital. Apresenta perfuração no lado direito } \\
\text { do frontal. Não apresentou marcas de desenvolvimento de nenhum segmento muscular específico. } \\
\text { Não apresentou fraturas. Foram radiografados um fêmur, rádios e úmeros. Observou-se densidade } \\
\text { heterogênea na cortical da diáfise do fêmur. Foram usados fragmentos de crânio (órbita, glabela, parte } \\
\text { inferior do parietal e occipital). Não foram observados sinais de neoformação óssea nesses } \\
\text { fragmentos. }\end{array}$ \\
\hline 4 & $\begin{array}{l}\text { Fragmentos de neurocrânio e face; maxila com } 15 \text { dentes articulados; corpos de vértebras lombares; } \\
\text { terço proximal do fêmur direito (radiografia descrita); terço médio e distal da tíbia esquerda } \\
\text { (radiografia descrita). Não apresentou marcas de desenvolvimento de nenhum segmento muscular } \\
\text { específico. Não apresentou fraturas. As radiografias indicaram aumento da densidade nas corticais da } \\
\text { diáfise e metáfise do fêmur e densidade aumentada nas corticais da diáfise, espessamento e } \\
\text { irregularidades na metáfice da tíbia.Foram usados fragmentos de diáfise de fêmur e tíbia para exame } \\
\text { histológico (cortes teciduais de aspecto basolítico amorfo de aspecto calcário). }\end{array}$ \\
\hline $7(\mathrm{~A})$ & $\begin{array}{l}\text { Fragmentos de osso de ílio e púbis; } 2 \text { fêmures (fragmentos dos terços proximais); fragmentos de } \\
\text { vértebras cervicais; fragmento de neurocrânio. Não apresenta alterações anatomopatológicas. } \\
\text { Fragmentos foram radiografados. Foram usados fragmentos de ílio e púbis para exame histológico } \\
\text { (cortes teciduais de aspecto calcário) }\end{array}$ \\
\hline
\end{tabular}




\begin{tabular}{|l|l|}
\hline $\begin{array}{l}\text { Sepultamento } \\
\text { (indivíduo) }\end{array}$ & \multicolumn{1}{c|}{ Fragmentos ósseos analisados } \\
\hline $7(\mathrm{~B})$ & $\begin{array}{l}\text { Fragmento de neurocrânio. Não apresenta alterações indicadoras de hiperosteose porótica. } \\
\text { Fragmentos foram radiografados. Foi usado fragmento de crânio para exame histológico (tecido de } \\
\text { aspecto calcário). }\end{array}$ \\
\hline 9 & $\begin{array}{l}\text { Fragmento do esterno, com orifício de bordas irregulares; 3 corpos de vértebras torácicas; um corpo } \\
\text { de vértebra lombar; terço proximal e médio do úmero esquerdo; terço distal e médio de ulna; } \\
\text { fragmento de osso do quadril direito; fêmur direito; terço proximal do fêmur esquerdo. Não } \\
\text { apresentou marcas de desenvolvimento de nenhum segmento muscular específico. Não apresentou } \\
\text { fraturas. Foram radiografados fragmentos ósseos não especificados. Foram usados fragmentos de } \\
\text { esterno, osso do quadril e fêmur (tecido de aspecto calcário). }\end{array}$ \\
\hline 10 & $\begin{array}{l}\text { Ossos do neurocrânio; fragmentos de ulna esquerda (radiografia descrita); fragmentos de úmero e } \\
\text { tíbia. Foi usado um fragmento de crânio para exame histológico (tecido de aspecto amorfo e calcário, } \\
\text { como os demais, sem sinais de alterações histopatológicas). }\end{array}$ \\
\hline
\end{tabular}

Quadro 4. Relação dos fragmentos ósseos empregados para o paleodiagnóstico de patologias nos esqueletos do sítio Pedra do Alexandre (adaptado de Santos, 1997: 181211).

Todos os esqueletos, segundo Santos (1997), estavam em região de solo ácido. O "paleodiagnóstico" proposto pelo autor baseou-se no exame macroscópico, radiológico e histológico dos ossos. O exame paleopatológico não indicou sinais sugestivos de traumas, tumores, anomalias e de doenças infecciosas nos esqueletos A e B (sepultamento 1). No indivíduo do sepultamento 2 foi observada pelo autor uma lesão craniana antemortem na região esquerda do frontal e superfícies com porosidade no teto da órbita, parietais e occipital. No indivíduo do sepultamento 4 , observou-se espessamento cortical nas diáfises do fêmur e da tíbia (exame radiológico). Nos fragmentos ósseos encontrados no sepultamento 7 (A e B), não foram observadas alterações, exceto material amorfo de aspecto calcário.

Os esqueletos encontrados nos sepultamentos 9 e 10 não apresentaram alterações ósseas nos exames radiológicos e histológicos. Santos (1997), entretanto, apresentou as hipóteses da presença de uma lesão perfurocontusa, de entrada, por 
trauma no frontal do esqueleto do sepultamento 2 e hiperosteose porótica e osteoporose no teto da órbita, frontal, parietal e occipital; e no esqueleto do sepultamento 4, possível sinal de osteíte deformante, indicado pelo aumento da densidade do tecido cortical. Entretanto, neste caso, não foi possível relacionar o aumento da densidade óssea com a hipótese diagnóstica da osteíte.

O processo de análise macroscópica empregado por Santos (1997) caracterizou-se pela formulação da hipótese diagnóstica, diagnóstico, diagnóstico diferencial e o paleodiagnóstico. O diagnóstico se dá em relação aos fatores extrínsecos e intrínsecos e em relação as variáveis internas e externas, que se manifestam na faixa somatológica e cultural. Os procedimentos metodológicos básicos empregados incluíram a consulta a coleções de referência em patologia óssea, análise macroscópica (anatomopatológica), exame radiológico e exame histológico (histopatológico).

Quanto ao contexto de escavação, os sepultamentos localizados em Pedra do Alexandre foram documentados por meio de fotografias, filmagem e uso de fichas de campo. Foram considerados sepultamentos primários, secundários e aqueles que se encontravam perturbados (incompletos, primários ou secundários, com dispersão ou ossos avulsos). A planta baixa preliminar dos sepultamentos apresenta a distribuição espacial da maior parte das deposições. Na Figura 2, uma planta apresenta a distribuição dos sepultamentos escavados no sítio até 2016. 


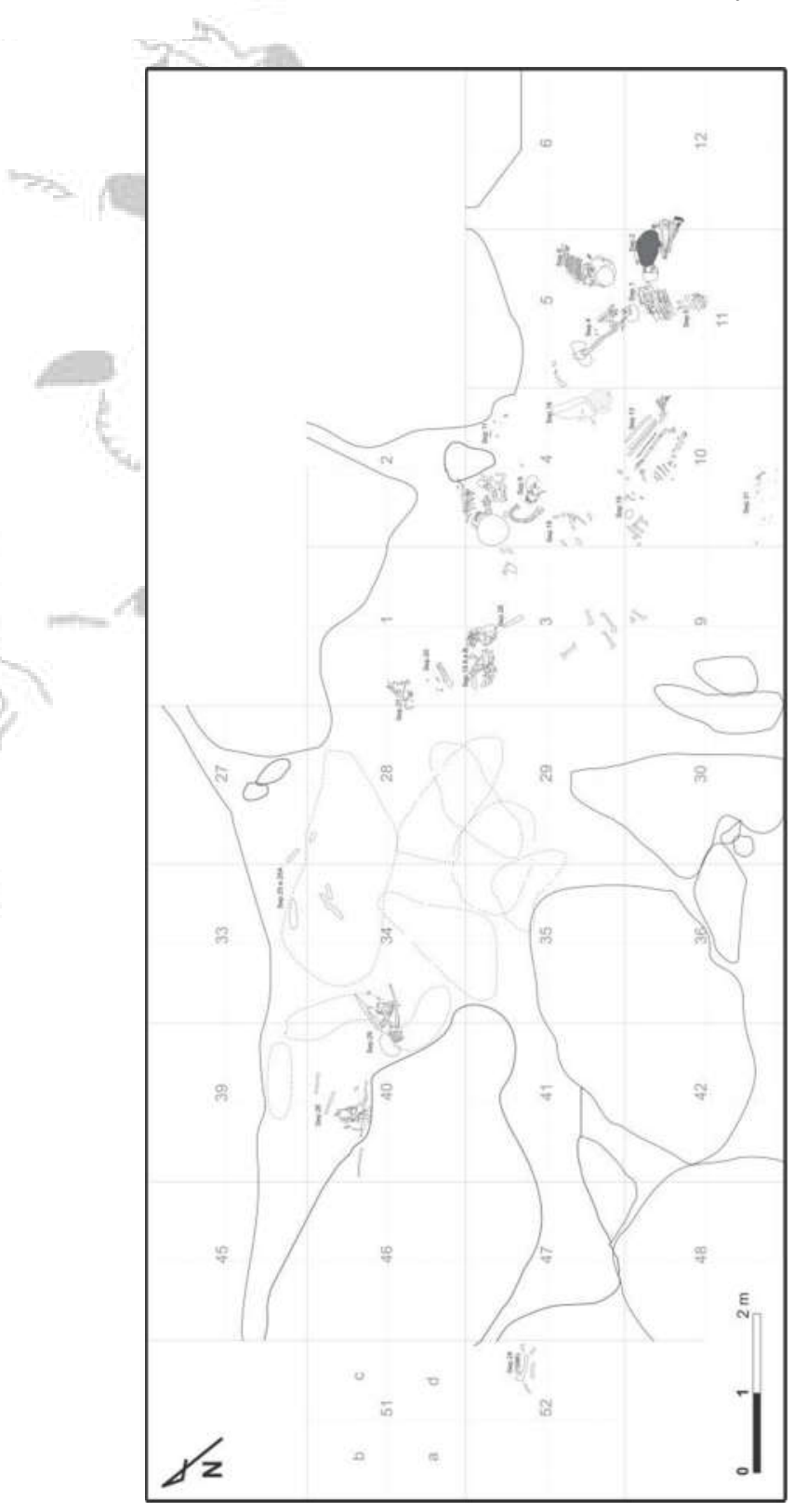

Figura 2. Planta baixa dos sepultamentos escavados no sítio Pedra do Alexandre, Rio Grande do Norte, Brasil (Fonte: adaptado por Carolina Sá, Ana Solari, 2019) 
Alguns exemplos de tipos de deposições funerárias estão na Figura 3. O sepultamento 1 foi classificado como sepultamento secundário (ou deposição composta), o sepultamento 2 como sepultamento primário (ou deposição simples). Os sepultamentos de indivíduos infantis em grande número, próximo do número dos adultos, representou uma característica do perfil funerário deste sítio. Outros sepultamentos como o 15 apresentou dois conjuntos de ossos fora de conexão anatômica, denotando fazerem parte de uma deposição composta ou secundária. Este foi classificado preliminarmente como uma deposição secundária dupla.

Os adornos corporais escavados nos sepultamentos de Pedra do Alexandre (Figura 4), foram estudados em conjunto com adornos de outros sítios arqueológicos do Nordeste brasileiro por Silva (2004), Castro (2009) e Santos (2020, no prelo). Estes foram acondicionados em reserva técnica separadamente dos ossos humanos. Seu potencial de análise e interpretação arqueológica vincula-se a: a) obtenção de dados sobre tecnologia e cadeia operatória da confecção e usos dos artefatos osteodontomalacológicos; b) obtenção de dados paleoambientais, incluindo os zooarqueológicos e paleobotânicos; c) obtenção de dados sobre subsistência; d) dados sobre contatos, trocas e migração; e) dados sobre identidade, status e gênero; f) dados sobre as relações entre o ser humano no ambiente, entre outros.

Entretanto, estudos que associem dados do perfil demográfico ou biológico dos indivíduos com seus acompanhamentos funerários (pigmentos, adornos corporais, 
armas, cerâmica, oferendas alimentares, entre outros) simultaneamente, ainda não foram produzidos no caso do sítio Pedra do Alexandre.

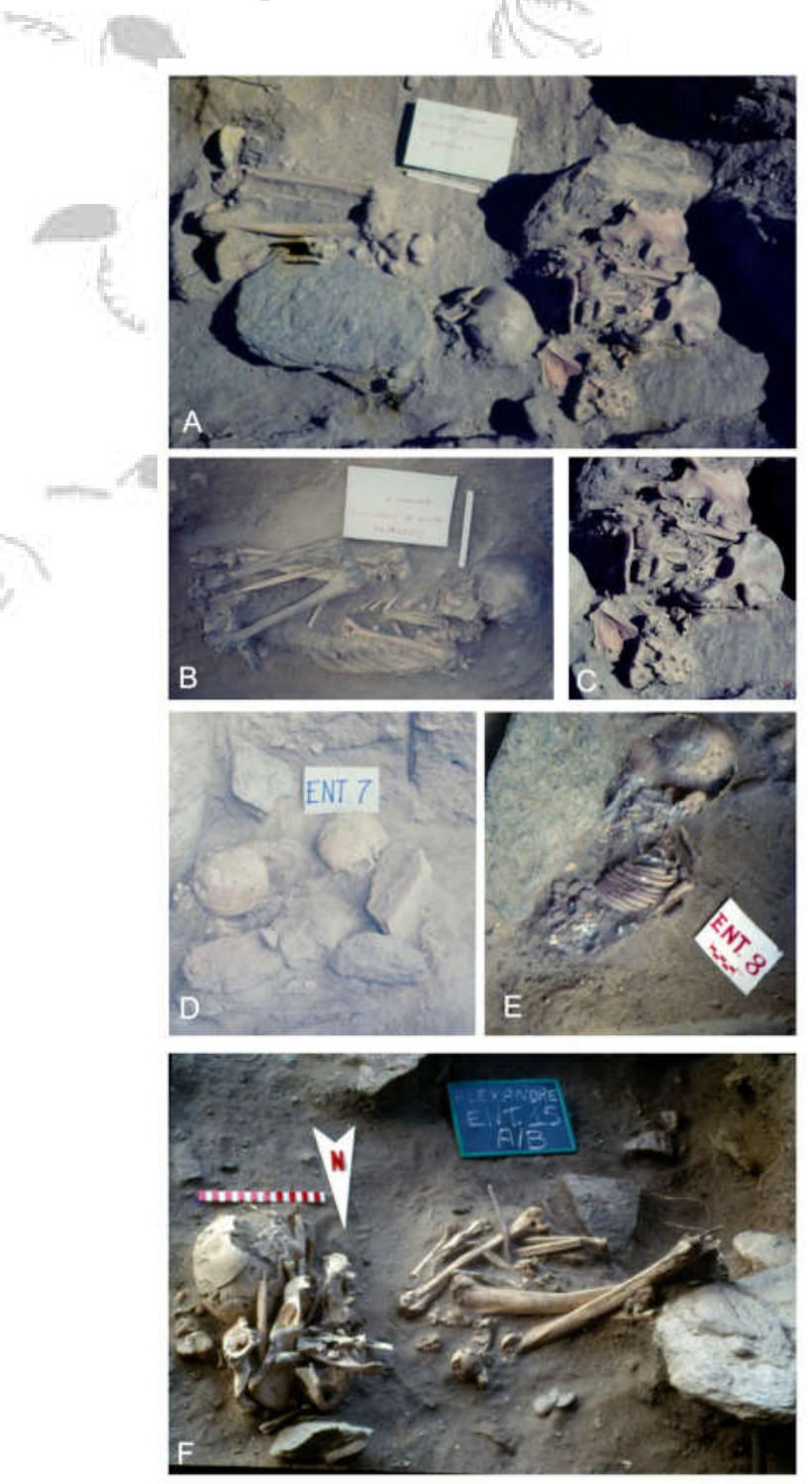

Figura 3. Exemplos de sepultamentos escavados em Pedra do Alexandre: A a C, Sepultamentos 1 e 2; D e E, Sepultamentos 7 e 8 , de subadultos; $\mathrm{F}$, Sepultamento 15, com indivíduos A e B (Fonte: Fundação Seridó, adaptado por Ana

Solari, 2019). 
$\mathrm{Na}$ coleção sensível formada pelos adornos corporais encontrados nos sepultamentos, observaram-se adornos em formas cilíndricas, confeccionados em diáfises de ossos de aves e mamíferos (contas de colar), contas circulares planas de valvas de molusco polidas, contas feitas com dentes de mamíferos e com valvas de moluscos perfuradas.

Na Figura 4, em A e B, estão exemplos de contas cilíndricas tubulares, de diáfises de ossos longos de animal; em $\mathrm{C}$ e $\mathrm{D}$, contas em forma de coroa circular de valva de molusco perfurada e polida; contas de dentes de mamíferos perfurados estão exemplificadas em E e G; valvas de gastrópode marinho perfuradas podem ser observadas em F; em H e J, contas fusiformes de diáfise de osso de animal; em I, K e L, contas cilíndricas em osso de animal polido; contas tubulares de diáfise de ossos de animais em M; um pingente em osso de animal perfurado em $\mathrm{N}$; contas esféricas feitas de valvas de moluscos polidas e perfuradas em $\mathrm{O}, \mathrm{P}$ e Q; e em R, contas cilíndricas de diáfises de ossos de animais cortadas.

Os adornos foram confeccionados preferencialmente com diáfises de ossos longos de pequenos animais (mamíferos e aves), de cervídeos, dentes de Allouata sp. (bugio), valvas de moluscos, incluindo a Olivella sp., encontradas em bancos de areia, na planície litorânea. Alguns desses adornos podem ser indicadores de trocas com outros grupos costeiros e/ou migrações para as zonas litorâneas. Esta questão 
ainda não foi abordada em relação as valvas de gastrópodes marinhos associadas em dois indivíduos de Pedra do Alexandre.

As contas cilíndricas tubulares e em forma de coroa circular, em osso de animal e valva de molusco, foram encontradas associadas no esqueleto primário de jovem do sepultamento 1 (um adulto jovem e dois subadultos). No sepultamento 6 (com subadultos) foram localizadas, em associação, contas de dentes de bugio e de valvas de gastrópode marinho (gênero Olivella $\mathrm{sp}$ ). Associadas ao sepultamento 15 (dois adultos jovens), foram localizadas as contas de colar cilíndricas, em osso de animal.

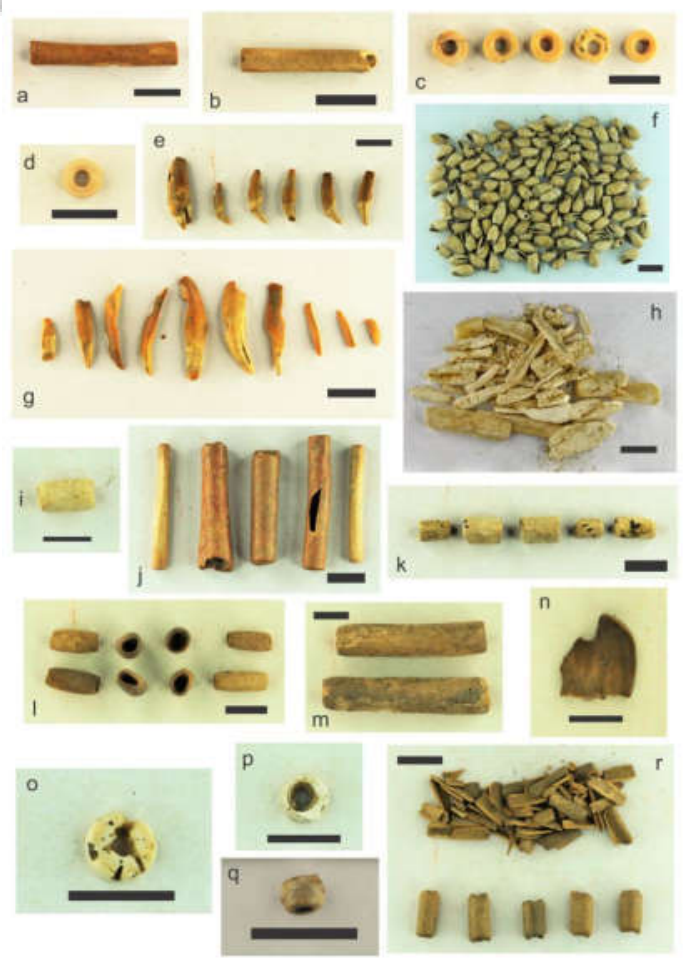

Figura 4. Exemplos de tipos de adornos corporais encontrados nos sepultamentos de Pedra do Alexandre, RN, Brasil. Escalas = $1 \mathrm{~cm}$. Elaborada por Ana Solari, 2020. 
Durante uma nova revisão dos dados referentes aos sepultamentos do sítio Pedra do Alexandre realizada pelos autores deste artigo, foi elaborado o Quadro 5.

Diferentemente de Santos (1997), foram considerados todos os indivíduos da coleção antropológica, diretamente analisados em laboratório, revista a documentação de campo e feitas revisões em casos de sepultamentos em algumas campanhas de campo. A revisão dos números das deposições funerárias em laboratório (LABIFOR-UFPE), fundamentada na análise osteológica comparada do material ósseo e da sua documentação de campo, resultou nesta nova elaboração da distribuição dos registros de campo (sepultamentos). O sepultamento 14 não consta na relação. Os "sepultamentos" 23 e 24 - campanha 14, 26 (atual 23) - campanhas 10 e 11, e 29 (antigo 22) -campanha 16 foram escavados todos dos mesmos setores "Área da capela" ou "Garrincho", contendo vários indivíduos com ossos muito fragmentados e misturados. Poderiam ser parte dos mesmos depósitos primários ou secundários perturbados por fatores tafonômicos naturais e/ou antrópicos. Esta relação foi elaborada por Sérgio F S M Silva, do LABIFOR-UFPE e ampliada durante o pós-doutoramento de Ana Solari, entre 2012 e 2018. 


\begin{tabular}{|c|c|c|c|c|c|c|c|}
\hline $\begin{array}{l}\text { Número da } \\
\text { Deposição } \\
\text { Funerária }\end{array}$ & NMI & \multicolumn{2}{|c|}{$\begin{array}{l}\text { Sepultamento } \\
\text { (número de } \\
\text { campo) }\end{array}$} & $\begin{array}{c}\mathrm{N}^{\circ} \\
\text { Individuo }\end{array}$ & Idade & Sexo & Observações: \\
\hline \multirow[t]{5}{*}{3} & \multirow{5}{*}{4} & \multirow[t]{4}{*}{$1\left(+5^{*}\right)$} & \multirow[t]{4}{*}{ Sim } & $1 \mathrm{~A}$ & $\begin{array}{l}\text { Adulto } \\
20 \text { a } 22 \\
\text { anos }\end{array}$ & $\mathrm{M}$ & \multirow{4}{*}{$\begin{array}{l}\text { Inumação secundária múltipla. } \\
\text { Com ocre. Feto a termo sem ocre (1 } \\
\text { D). Adornos funerários. }\end{array}$} \\
\hline & & & & $1 \mathrm{~B}$ & $\begin{array}{c}\text { Subadulto } \\
10 \mathrm{a} \pm 30 \mathrm{~m}\end{array}$ & I & \\
\hline & & & & $1 \mathrm{C}+\left(5^{*}\right)$ & $\begin{array}{l}\text { Subadulto } \\
1 \mathrm{a} \pm 4 \mathrm{~m}\end{array}$ & I & \\
\hline & & & & $1 \mathrm{D}$ & $\begin{array}{c}\text { Subadulto } \\
\text { Feto a } \\
\text { termo } \\
\text { (38 a } 40 \\
\text { sem.) }\end{array}$ & I & \\
\hline & & $5 *$ & Não & - & - & - & $\begin{array}{l}\text { 5* Não é outro sepultamento, é o } \\
\text { mesmo individuo do sepultamento } \\
\text { 1-C. }\end{array}$ \\
\hline 2 & 1 & 2 & Sim & 2 & $\begin{array}{l}\text { Adulto } \\
\text { jovem } \\
16 \text { a } 18 \\
\text { anos }\end{array}$ & $\mathrm{M}$ & $\begin{array}{l}\text { Inumação primária simples. } \\
\text { Adornos funerários }\end{array}$ \\
\hline 3 & 3 & 3 & $?$ & 3 & $\begin{array}{c}\text { Subadulto } \\
5 \mathrm{a} \pm 12 \mathrm{~m} \\
(+ \text { feto a } \\
\text { termo e } \\
\text { adulto) }\end{array}$ & I & $\begin{array}{l}\text { Inumação primária/ secundaria } \\
\text { simples com perturbação? (ossos } \\
\text { intrusivos de feto e adulto) }\end{array}$ \\
\hline 4 & 1 & 4 & Sim & 4 & $\begin{array}{l}\text { Adulto } \\
(25 \text { a } 35 \\
\text { anos })\end{array}$ & $F ?$ & $\begin{array}{l}\text { Inumação primária simples. Com } \\
\text { adornos }\end{array}$ \\
\hline 6 & 3 & 6 & $?$ & 6 & $\begin{array}{l}\text { Subadulto } \\
\text { indet. } \\
\text { Subadulto } \\
\text { (4/5 anos } \\
\text { aprox.) } \\
\text { Adulto }\end{array}$ & I & $\begin{array}{l}\text { Inumação secundária perturbada? } \\
\text { Inumação primária perturbada? } \\
\text { Importantes adornos funerários. }\end{array}$ \\
\hline 7 & 2 & 7 & Sim & $7 \mathrm{~A}$ & $\begin{array}{c}\text { Subadulto } \\
(4 \mathrm{a} \pm 12 \\
\mathrm{m})\end{array}$ & & ção primár \\
\hline & & & & $7 \mathrm{~B}$ & $\begin{array}{l}\text { Subadulto } \\
(7 \mathrm{a} \pm 24 \\
\mathrm{m})\end{array}$ & I & 7 \\
\hline 8 & 1 & 8 & Sim & 8 & Subadulto & I & $\begin{array}{l}\text { Inumação primária simples. } \\
\text { Adornos. }\end{array}$ \\
\hline
\end{tabular}




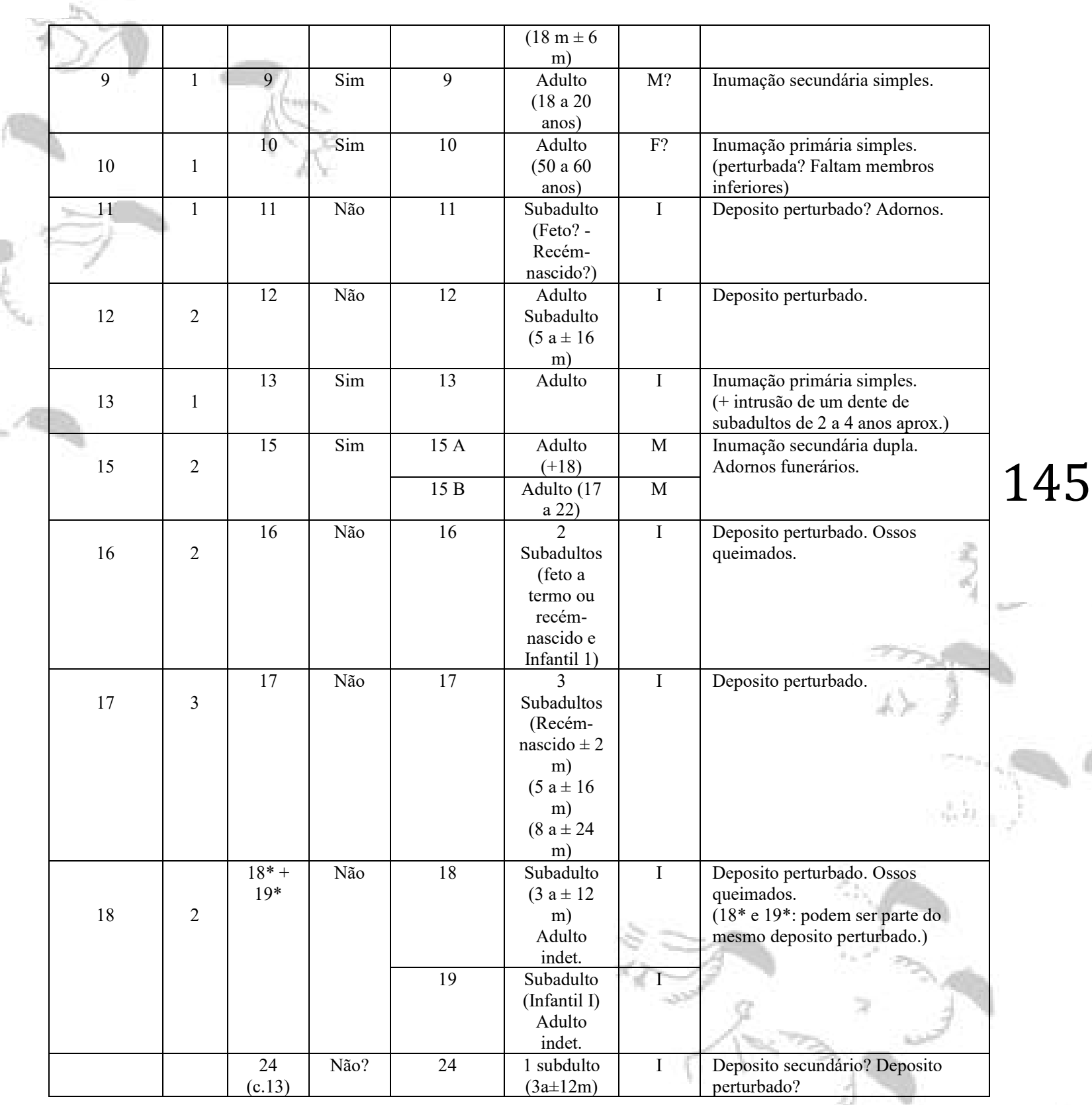




\begin{tabular}{|c|c|c|c|c|c|c|c|}
\hline 19 & 3 & & $\mathrm{~N}$ & & $\begin{array}{c}1 \\
\text { adolescente } \\
\text { (7-8 anos) } \\
1 \text { adulto } \\
\text { indet. } \\
\end{array}$ & & \\
\hline $\begin{array}{r}20 \\
-10 \\
\end{array}$ & 3 & $\begin{array}{l}23^{*+} \\
24^{*} \\
(\mathrm{c} .14)\end{array}$ & Não & $?$ & $\begin{array}{c}1 \\
\text { Adolescent } \\
\text { e (14 a 16) } \\
2 \text { Adultos } \\
(+18 / 20)\end{array}$ & $\begin{array}{l}2 \mathrm{M} \\
1 \mathrm{~F}\end{array}$ & $\begin{array}{l}23 *+24 * \text { Deposito perturbado. } \\
\text { (Mesmo depósito }=\text { ossos podem } \\
\text { ser reconstituídos) }\end{array}$ \\
\hline 21 & $\begin{array}{l}2 ? \\
\text { (ind) }\end{array}$ & $\begin{array}{c}25 \\
(\text { atual } \\
21 \mathrm{e} \\
22) \\
\end{array}$ & ? & $\begin{array}{l}25 \text { e } 25 \mathrm{~A} \\
\text { (atual } 21 \mathrm{e} \\
22 \text { ) }\end{array}$ & $\begin{array}{l}\text { Adulto } \\
\text { indet. }\end{array}$ & I & Deposito perturbado? \\
\hline 22 & 3 & $\begin{array}{l}26 \\
\text { (atual } \\
23)\end{array}$ & Não & $\begin{array}{c}26 \\
\text { (atual 23) }\end{array}$ & $\begin{array}{l}\text { Adulto (1) } \\
\text { Subadultos } \\
\text { (2) }\end{array}$ & $\begin{array}{l}\mathrm{M} \\
\mathrm{I}\end{array}$ & Deposito perturbado. \\
\hline \multirow[b]{2}{*}{23} & \multirow[b]{2}{*}{1} & $\begin{array}{l}27+ \\
20^{*}\end{array}$ & Sim & 27 & Adulto & F & $\begin{array}{l}\text { Inumação primária simples } \\
\text { (perturbada). Escavado em } 2 \\
\text { campanhas. }\end{array}$ \\
\hline & & $20^{*}$ & Não & - & - & - & $\begin{array}{l}20^{*} \text { Constitui parte inferior do } \\
\text { esqueleto do Sepultamento } 27, \\
\text { conforme análise e reconstituição } \\
\text { no Laboratório (LABIFOR-UFPE) }\end{array}$ \\
\hline 24 & 5 & $\begin{array}{c}28 \\
\text { (ex.21) }\end{array}$ & Não & - & $\begin{array}{c}2 \\
\text { subadultos? } \\
3 \text { adultos? }\end{array}$ & I & Deposito perturbado. \\
\hline \multirow[t]{2}{*}{25} & \multirow[t]{2}{*}{4} & \multirow{2}{*}{$\begin{array}{c}29 \\
(\mathrm{ex} .22) \\
+\mathrm{CO} 1\end{array}$} & Sim? & $?$ & Adulto. & $\mathrm{M}$ & $\begin{array}{l}\text { Inumação primária simples } \\
\text { perturbada? }\end{array}$ \\
\hline & & & Não & $?$ & $\begin{array}{l}2 \text { Adultos e } \\
1 \\
\text { subadulto. }\end{array}$ & I & Deposito perturbado. \\
\hline 26 & 1 & $30+31$ & Sim? & & Adulto & $\mathrm{F} ?$ & $\begin{array}{l}\text { Inumação primária simples? } \\
\text { (perturbada) }\end{array}$ \\
\hline
\end{tabular}

Quadro 5. Dados coletados na Reserva Técnica de Vestígios Orgânicos do Departamento de Arqueologia da UFPE referentes aos esqueletos do sítio Pedra do Alexandre: número da deposição funerária (revisto), número mínimo de indivíduos, número do sepultamento registrado em campo, número do esqueleto, idade, sexo e observações sobre características da deposição funerária. Observações: $\mathrm{F}$ - feminino, $\mathrm{M}$ - masculino, I - sexo indeterminado.

A formação de uma coleção antropológica sensível a partir da escavação do sítio propiciou, mais a partir de 2014, o desenvolvimento de pesquisas básicas e aplicadas sobre problemas relacionados as características dentárias, na perspectiva 
da Antropologia dental, da Paleopatologia e Arqueologia da doença e da Bioarqueologia da infância.

Solari et al. (2016a) observaram, a partir de 30 indivíduos que apresentaram dentes (de um NMI maior que 26 e menor que 53 indivíduos), provenientes de 17 sepultamentos (de 26 deposições funerárias) do sítio Pedra do Alexandre, 284 dentes articulados e desarticulados, decíduos e permanentes em vários estágios de desenvolvimento. O inventário e seleção dos dentes resultou na estimativa da idade, ancestralidade biogeográfica, obtenção de dados odontométricos e sobre patologias dentárias. $\mathrm{Na}$ amostra dentária total, 128 (45\%) dentes estavam articulados nos respectivos alvéolos e 156 (55\%) encontravam-se desarticulados ou avulsos. Foram analisados 167 (59\%) dos dentes, entre articulados e desarticulados/avulsos. Entre os 284 dentes observados, 117 (41\%) apresentavam-se fragmentados, sem condições de análise, apresentando sinais de alterações tafonômicas postmortem (Gráficos 2 e 3).

Foram empregados métodos propostos na bibliografia especializada de Antropologia Biológica e Antropologia Dental para o estudo da idade, morfologia dentária, indicadores de estilos de vida, doenças, traumas e anomalias. Nesta pesquisa, foram registrados em fichas de inventário dental (odontogramas) e fotografias as características de perda dental, doenças, traumas e anomalias, graus de desgaste e alterações tafonômicas. 


\section{Amostra de dentes de Pedra do Alexandre: dentes fragmentados e íntegros}

200

100

0

Gráfico 2. Quantificação dos dentes íntegros e fragmentados do sítio Pedra do Alexandre, considerando um $n=284$ dentes (Adaptado de Solari et al. 2016a)
167

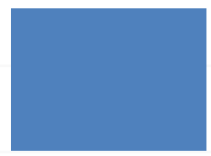

íntegros e analisados
117

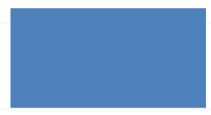

fragmentados e não analisados
200

100

0

\section{Amostra de dentes de Pedra do Alexandre: dentes fragmentados e íntegros}

128

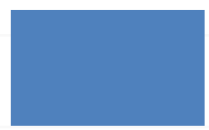

articulados nos alvéolos
156

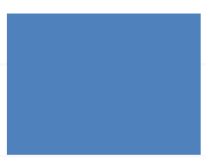

desarticulados avulsos

Gráfico 3. Quantificação dos dentes articulados (45\%) e desarticulados (55\%) analisados na coleção do sítio Pedra do Alexandre, considerando um n=284 dentes. (Adaptado de Solari et al. 2016a)

Entre as patologias, foram observadas a presença de cálculo, cárie, absorção alveolar, abcessos, defeitos de formação do esmalte, quebras e fissuras. A estimativa da idade considerou a sequência do desenvolvimento e erupção dentária. Indivíduos com presença de terceiros molares erupcionados foram classificados como adultos. A pesquisa de Solari et al. (2016a) indicou em um conjunto de 30 indivíduos, 16 (53\%) adultos e 14 (47\%) subadultos (Gráfico 4), estes com idades 
entre menos de 2 meses e pouco mais de 10 anos. A presença de subadultos nessa faixa etária pode indicar mortalidade neonatal (complicações no parto) e a presença de doenças ocorridas durante a amamentação, desmame, acréscimo de alimentos à dieta, entre 1 a 3 anos, como também outras causas de mortalidade em crianças maiores.

\section{Percentuais de adultos e subadultos do sítio Pedra do Alexandre (NMI=30)}

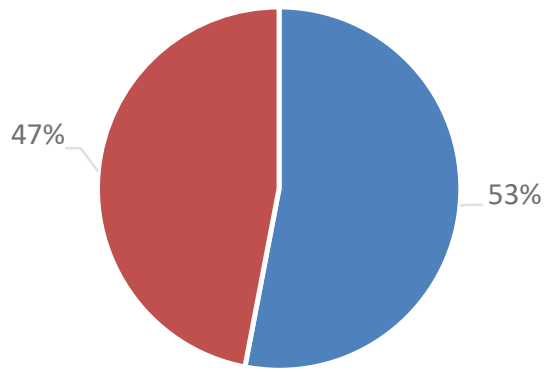

Gráfico 4. Quantidades em percentuais de adultos $(n=16)$ e subadultos $(n=14)$ estimados por Solari et al. (2016a) em 30 indivíduos do sítio Pedra do Alexandre.

No sítio Pedra do Alexandre, as crianças em idade de desmame, a partir dos 3 anos de idade, começaram a ingerir alimentos sólidos, como os adultos, o que foi observado pela presença de desgastes moderados e intensos, principalmente nos molares decíduos. Elementos abrasivos nos alimentos (dieta) e ações de processamento de alimentos e artefatos (desgaste extramastigatório, ocupacional) 
poderiam ter ocasionado os desgastes planos nos adultos, que atingiam de forma leve, moderada ou intensa as superfícies oclusais. O padrão de desgaste plano afetou os pré-molares e molares nos adultos e subadultos. O desgaste moderado nos dentes anteriores é indicativo de práticas extramastigatórias, associadas a atividades diversas.

A maior parte dos adultos, segundo Solari et al. (2016a), apresentou pouca incidência de cálculo dentário, cárie, abcessos e linhas hipoplásicas. Ocorreram exceções, como o indivíduo A do sepultamento 29. Este apresentou desgaste acentuado, oblíquo, lesões cariosas severas, cálculo leve a moderado e intenso, exposição da câmara pulpar. A dieta abrasiva adotada pela maioria dos indivíduos - com consumo menor de açúcares e carboidratos, impediu ou diminuiu a formação de lesões cariosas. Caracteres epigenéticos dentários, como os incisivos em forma de pá nos graus 1 e 2 (sistema ASUDA), podem estar relacionados a ancestralidade americana da população do Pedra do Alexandre. Quanto à análise odontométrica, foi identificado um caso de microdontia no indivíduo A do sepultamento 28. Neste indivíduo foi observada possível condição patológica relacionada ao crescimento restringido do esqueleto. $\mathrm{O}$ esqueleto apresentou indicadores de baixa estatura idiopática, hipopituarismo, síndrome de Laron ou hipotiroidismo. Entretanto, pela ausência da maior parte dos ossos deste esqueleto, as hipóteses não puderam ser testadas. 
A amostra dentária do sítio Pedra do Alexandre, embora reduzida, propiciou as seguintes considerações (SOLARI et al., 2016a): a) o desgaste dentário em subadultos e as idades de morte informam sobre a mortalidade infantil, idade de desmame e tipo de alimentação; b) a presença de incisivos em forma de pá indicou a ancestralidade americana dessa população; c) observaram-se, predominantemente, desgastes mastigatórios e extramastigatórios (desgaste dos incisivos) e tártaro, este em adultos e subadultos; d) registrou-se a ausência de cárie (excetuando-se o esqueleto do sepultamento 29) em indivíduos adultos e subadultos. O desgaste oclusal de tipo plano dos molares, desgaste dos dentes anteriores e ausência de lesões cariosas indicam a presença de uma dieta abrasiva, com alimentos duros, fibrosos e pobres em carboidratos, assim como atividades de uso dos dentes anteriores como instrumentos, aproximando esta população de formas de subsistência relacionadas aos caçadores-coletores. Carências alimentares e lesões cariosas representam exceções.

Posteriormente, a amostra estudada por Solari et al. (2016a) foi ampliada de 30 indivíduos (somente os que possuíam dentes) para 48 ( 25 sudadultos e 23 adultos) em uma arqueologia aplicada ao estudo dos indivíduos infantis. Esta nova pesquisa, ainda em caráter preliminar, iniciada por Solari et al. (2016b), ainda deve ser ampliada, considerando-se as características da coleção antropológica.

A presença infantil no registro bioarqueológico mostrou-se significativa no caso do sítio Pedra do Alexandre (SOLARI et al., 2016b). Este estudo considerou a análise 
curatorial da coleção antropológica sensível (coleção bioarqueológica) deste sítio, formada inicialmente entre 2009 e 2011. Os subadultos (fetos, recém-nascidos, crianças e adolescentes) compreenderam um $\mathrm{NMI}=25$. Constituem partes de deposições funerárias simples, compostas e perturbadas por agentes naturais e ou antrópicos, durante o período de ocupação do espaço funerário. A preservação dos esqueletos infantis é bastante deficitária, mas não impediu a percepção de um número significativo desses indivíduos.

Os esqueletos infantis de Pedra do Alexandre foram recuperados em diferentes tipos de deposições funerárias (simples, compostas) e nas deposições perturbadas por agentes tafonômicos naturais e/ou antrópicos (conjuntos ósseos com mais de um indivíduo, muito incompletos), entre ossos queimados, humanos e não-humanos. O nível de representatividade dos esqueletos de subadultos em escavações arqueológicas pode variar conforme a ação de agentes tafonômicos e sua relação com os processos de conservação/decomposição óssea e com determinadas práticas funerárias.

Adultos e subadultos (fetos, recém-nascidos, crianças, adolescentes) foram inumados no mesmo espaço funerário, sem evidências de discriminação por classe etária e em covas conjuntas com adultos femininos ou masculinos. $\mathrm{O}$ número mínimo de subadultos $(\mathrm{NMI}=25)$ suplantou o número de adultos analisados $(\mathrm{NMI}=23)$ em uma segunda amostragem, conforme o Gráfico 5 (SOLARI et al., 2016b), desconsiderando-se o número mais provável de indivíduos como um todo. 
Essa nova quantificação considerou dados comparados de comprimentos de ossos longos e níveis diferentes de desenvolvimento dentário e ósseo (este último, quando possível, devido ao estado acelerado da decomposição óssea). A presença de um número significativo de subadultos no depósito arqueológico é um indicativo de dificuldades de adaptação e de sobrevivência, possivelmente associadas a causas endógenas ou exógenas, aborto, anormalidades genéticas, baixo peso ao nascer, prematuridade e parto traumático.

\section{Número de esqueletos de adultos e subadultos do sítio Pedra do Alexandre ( $\mathrm{NMI}=48)$}

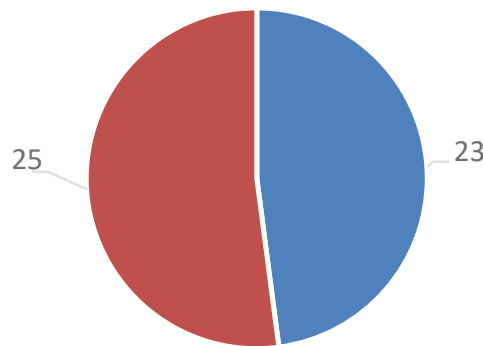

- Adultos - Subadultos

Gráfico 5. Quantidades de adultos e subadultos estimadas por Solari et al. (2016b) em 48 indivíduos do sítio Pedra do Alexandre.

As causas exógenas, segundo Solari et al. (2016b), podem estar representadas por doenças infecciosas, desmame, acidentes e nutrição deficiente. Essas causas são de 
identificação complexa, dependendo do estado de conservação dos ossos e dentes destes indivíduos.

Incisivos decíduos e permanentes em forma de pá (shoveling, double-shoveling), conforme o sistema ASUDAS, indicaram ancestralidade americana para os indivíduos subadultos. Dentes decíduos e permanentes apresentaram desgaste oclusal plano, variando de leve a moderado e severo nas crianças com mais de 3 anos de idade, especialmente nos molares, não sendo registradas patologias dentárias. Nas crianças entre 7 e 10 anos, observou-se a presença de cálculo dentário leve. Por causa da presença de desgaste moderado a severo nos dentes decíduos, possivelmente teriam sido introduzidos alimentos sólidos com elementos abrasivos na dieta dos subadultos.

O desmame dos subadultos de Pedra do Alexandre teria ocorrido aos 3 anos de idade, ou menos. Assim, as crianças, logo após o desmame, já teriam incorporado a dieta dos adultos. Nesta pesquisa de Solari et al. (2016b), foram identificadas as seguintes características na coleção: a) incompletude e hiperfragmentação dos esqueletos por fatores naturais e antrópicos diversos; b) mistura de ossos e dentes de indivíduos de sexos e idades diferentes; c) fragilização dos ossos e dentes devido ao estado de decomposição dos mesmos. Alterações tafonômicas ocorridas durante o processo de formação do sítio arqueológico - ação das águas, tipo de solo, diagênese, reutilização constante do espaço para fins funerários, queda de blocos do abrigo -, derivadas da própria complexidade do registro arqueológico, resultaram 
em fatores determinantes na preservação e conservação dos esqueletos e seus adornos e acompanhamentos, do seu contexto de deposição funerária.

Segundo Solari et al. (2016b), as abordagens científicas da Bioarqueologia da infância, da Arqueotanatologia e da Arqueologia funerária tornam possível a revisão de temas sobre a sobrevivência e limites do registro bioarqueológico infantil, em primeiro lugar; e em segundo, sobre as características da mortalidade infantil, idade, sexo, ancestralidade, dieta e desnutrição infantil; sobre as doenças, traumas e anomalias. Isso por causa da presença infantil significativa neste sítio: os ossos infantis representam um dos potenciais de análise e interpretação arqueológica do sítio a partir da coleção institucionalizada, maximizando ou minimizando os resultados esperados; e demandando ou não novas tecnologias de investigação arqueológica. A coleção de remanescentes deste sítio carece de estudos que associem dados morfogeométricos comparados com grandes conjuntos de dados de outros sítios da região e destes com dados biomoleculares, isotópicos e histomorfométricos.

Uma sensível predominância de indivíduos subadultos sobre os indivíduos adultos ainda não pode ser observada na sua totalidade, mesmo considerando que foram registradas em campo deposições funerárias perturbadas, isso devido a incompletude da escavação do sítio Pedra do Alexandre. As crianças podem ter sido consideradas como membros ativos da sociedade, portando adornos funerários, 
ocupando a mesma área funerária dos adultos e possuindoo traços de desgaste dentário indicadores das dietas dos adultos.

A mortalidade infantil, representada nas deposições funerárias de Pedra do Alexandre, podem ser o resultado de dificuldades de adaptação e sobrevivência, associando-se a causas endógenas e exógenas, principalmente, ainda não claramente verificadas, como eventos de fome/nutrição deficiente, infecções bacterianas ou virais, verminoses, abortos, traumas, desmame, infanticídio, conflitos, anormalidades genéticas, prematuridade, partos traumáticos, entre outras. A dificuldade de estimativa morfológica do sexo nos subadultos diminui o potencial interpretativo dos resultados até agora obtidos.

Nota-se o desmame aos três anos de idade, pelo menos, e a introdução de alimentos da dieta dos adultos desde essa idade. O texto de Solari et al. (2016b) deixa evidente a necessidade da aplicação de técnicas de análise microscópica eletrônica dos tecidos ósseos e dentários, de isótopos estáveis, de técnicas de análise paleodemográfica e técnicas de diagnose sexual que considerem os dentes nesse processo, auxiliando na confirmação, remodelação ou exclusão de hipóteses até então formuladas.

O estudo das patologias nos remanescentes de subadultos do sítio Pedra do Alexandre foi preliminarmente iniciado por Solari et al. (2018). Essas pesquisadoras associaram dados mortuários de Pedra do Alexandre, Rio Grande do 
Norte, com os da Toca do Gongo III, no Piauí. Consideraram que a presença de remanescentes de subadultos no registro arqueológico é um forte indicador de determinadas circunstâncias biológicas e socioculturais de grupos humanos do passado. A exposição dos seres humanos a traumas e doenças auxiliam na compreensão dos estilos de vida nesses sistemas socioculturais. A visibilidade dessas doenças e traumas representa um problema de pesquisa arqueológica muito importante na perspectiva interpretativa da arqueologia moderna.

$\mathrm{O}$ registro bioarqueológico apresenta traços da ação decompositora (ou preservativa) dos processos tafonômicos. Esses traços podem ser a falta de sinais de doenças, traumas, anomalias, carreados com os tecidos ósseos nos quais se manifestaram durante a decomposição do corpo e dos ossos. Nesse aspecto, segundo Solari et al. (2018), pode-se considerar que os sinais das doenças, traumas e anomalias não podem ser observados, representando para o arqueólogo as denominadas "patologias invisíveis". As amostras bioarqueológicas analisadas neste caso, provenientes de Pedra do Alexandre e Toca do Gongo III, apresentaram ausência de sinais de doenças que pudessem ser observados nos ossos. Em 36 indivíduos analisados nos dois sítios arqueológicos, não foram observados sinais de doenças. Entretanto, essa constatação não indica que tais doenças não existiram, considerando que a faixa etária de vários indivíduos indica uma baixa expectativa de vida. 
A presença de esqueletos incompletos, fragmentados, com severa decomposição óssea e sem sinais observáveis de doenças nos dois sítios pesquisados por Solari et al. (2018), no âmbito da Bioarqueologia da Infância, indica a necessidade de se repensar a relação entre as doenças que efetivamente acometeram as populações vivas e as "patologias invisíveis" não observadas nas coleções arqueológicas. O contexto arqueológico deve auxiliar a pensar o contexto sistêmico ou de vida de populações do passado. Entretanto, deve-se considerar a existência de dados incompletos, fragmentários, vestigiais que podem impedir determinadas diagnoses de doenças, traumas e anomalias, que por outro lado podem ser inferidas a partir de indicadores do perfil biológico individual e coletivo.

\section{CONCLUSÕES: NOVAS PERSPECTIVAS PARA O FUTURO}

A reconstrução da pesquisa que vem sendo realizada no sítio arqueológico Pedra do Alexandre demanda a contínua recuperação de frações muitas vezes desconectadas de estudos e resultados de diferentes níveis de complexidade, produzidos dentro de contextos acadêmicos e temporais distintos. Obviamente, a coleção antropológica sensível (utilizando aqui uma terminologia do ICOM, dos anos 1980), possui um potencial de análise e interpretação bastante amplo e importante para a compreensão do povoamento do Nordeste, das continuidade e mudanças socioculturais e das relações entre os seres humanos e o meio ambiente entre, pelo menos, cerca de 2.000 a $10.000 \mathrm{BP}$. 
Dentro de um contexto do sítio Pedra do Alexandre, com foco de interesse de pesquisa nas práticas funerárias e nas análises bioarqueológicas e de artefatos relacionados ao contexto funerário, foram descritos os principais autores (RAMOS, 1992，1994，1995，1995-1996; MARTIN，1994，1995-1996; QUEIROZ \& CARDOSO, 1995; MELLO E ALVIM et al., 1995-1996; SANTOS, 1997; QUEIROZ, 2002; SANTOS, 2010, 2014; FARIAS, 2013; SOLARI et al., 2015; SOLARI et al., 2016a; SOLARI et al., 2016b; SOLARI et al., 2018). Em um contexto comparado, no qual o sítio Pedra do Alexandre está inserido, em relação às práticas funerárias, podem ser considerados aqui os estudos de Martin (1999) Silva (2004), Castro (2009) e Santos (2020).

Os estudos sobre os remanescentes ósseos humanos escavados em Pedra do Alexandre durante cerca de uma década, apresentam uma quantidade importante de dados mortuários referentes a: a) quantificação do número de indivíduos, considerando as remodelações tafonômicas intensas que modificaram as deposições funerárias ao longo do tempo; b) dados preliminares sobre o perfil biológico (sexo, idade, ancestralidade, estatura, dados de antropologia dental, ancestralidade), fundamentais para uma reconstrução paleodemográfica; c) dados preliminares sobre sinais ósseos e dentários de doenças, traumas e anomalias, fundamentais para a reconstrução do modo de vida, padrões de estresses, subsistência e dieta; d) dados preliminares sobre aspectos arqueotanatológicos, referentes à caracterização das deposições funerárias no contexto arqueológico. Este último item demanda a 
análise aprofundada dos documentos produzidos em campo, associados à análise osteoarqueológica comparada com os mesmos.

Os estudos sobre os acompanhamentos funerários, desenvolvidos de forma mais geral e comparada por Silva (2004) e Castro (2009), e mais recentemente por Santos (2020), podem ser revisitados e seus dados comparados com a coleção de artefatos (acompanhamentos funerários) do Departamento de Arqueologia da UFPE.

As últimas pesquisas realizadas sobre os remanescentes humanos de Pedra do Alexandre (SOLARI et al., 2015; SOLARI et al., 2016a; SOLARI et al., 2016b; SOLARI et al., 2018) enfatizaram os esqueletos infantis, cuja presença é significativa no registro bioarqueológico, em relação aos adultos e características dentárias superficiais, no âmbito da antropologia dental.

Torna-se necessária a revisão sistemática da coleção antropológica, de forma integrada (associando esqueletos humanos e seus acompanhamentos funerários), com aplicação de técnicas arqueométricas e morfométricas voltadas ao esclarecimento de questões sobre diagênese; datação; diagnose sexual; isotopia relacionada à dieta e migrações; microscopia eletrônica de varredura em superfícies com traços relacionados a dieta e técnicas de tratamento em dentes, ossos e artefatos; análises micromoleculares para a identificação da matéria prima dos artefatos associados no contexto funerário. 
Na perspectiva dos estudos mais gerais sobre a pré-história do Nordeste, mais especificamente do Rio Grande do Norte, incluem-se os de caráter científico (MARTIN, 1999; MARTIN \& CASTRO, 1999; MARTIN et al., 2008) e os mais genéricos (NASSER, 1974; DANTAS, 1994; MEDEIROS, 1985; MACEDO, 1999).

Para o futuro, espera-se a comparação de caracteres na perspectiva da morfometria geométrica a partir de dados mínimos, de isótopos, de datações individuais e de DNA (quando possível) entre os grupos de Pedra do Alexandre e Lagoa Santa; e a (re)inclusão do primeiro nas rotas de povoamento de 9.000 a 10.000 BP. na Região Nordeste do Brasil. Serão necessárias novas intervenções arqueológicas minimamente invasivas, com coletas setorizadas e pormenorizadas de remanescentes humanos sob contexto de queda de blocos do abrigo, assim como o investimento na curadoria sistemática e investigativa de média e longa duração da coleção sensível de Pedra do Alexandre, com o reagrupamento de acompanhamentos funerários aos remanescentes humanos respectivos ${ }^{5}$. A presença de determinados tipos de gastrópodes encontrados entre os acompanhamentos funerários - associados as diferenças morfológicas entre os indivíduos - também podem indicar contatos e trocas (bio)culturais com populações do litoral. Este aspecto ainda não foi abordado nas pesquisas deste sítio.

\footnotetext{
${ }^{5}$ Esta etapa de curadoria foi iniciada quando da criação do LABIFOR - UFPE, em 2012 e aprimorada a partir de 2016, durante o pós-doutoramento de Ana Solari. Esta antropóloga física produziu um dossiê preliminar sobre a coleção de Pedra do Alexandre que incluiu dados dos esqueletos - de campo e laboratório - e acompanhamentos funerários.
} 
Portanto, tornam-se previsíveis estudos futuros nas perspectivas da Arqueometria (com ênfase nas possibilidades metodológicas e técnicas de datação); da Arqueotanatologia, visando a revisão dos contextos de deposição e redimensionamento de novas técnicas de escavação no sítio; da Bioarqueologia da infância e Arqueologia da doença; dos estudos paleoambientais aplicados; dos estudos em Tafonomia arqueológica, com ênfase na interpretação dos processos diagenéticos; em estudos aplicados de curadoria de curta, média e longa duração, com ênfase na conservação e preservação dos remanescentes humanos e seus acompanhamentos funerários.

\section{REFERÊNCIAS BIBLIOGRÁFICAS}

AGUIAR, Alice. 1982. "Tradições e estilos na arte rupestre no nordeste brasileiro". Clio, n.5. 91-104.

ALBANO, Rosângela. 1982. "Bibliografia sobre arte rupestre". Arquivos do Museu de História Natural, v. 4-5, 185-187.

ALMEIDA, Marcellus d'Almeida de. 2014. Análises tecnológicas e funcionais das indústrias líticas de quatro sítios arqueológicos no Seridó Potiguar. Dissertação de Mestrado, Programa de Pós-Graduação em Arqueologia, Universidade Federal de Pernambuco. Recife.

ASÓN VIDAL, Irma. 2010. "Escolhas simbólicas na ocupação dos Sítios com Arte Rupestre na área arqueológica do Seridó, RN, PB". Anais do Congresso Internacional de Arte Rupestre. FUMDHAMENTOS, v.2 (9), 77-81. 
. 1995-1996. "Las representaciones itifálicas en las pinturas rupestres de la tradición Nordeste, sub-tradición Seridó, Rio grande do Norte”. Clio - Série Arqueológica, v.1 (11), 141-151.

AZEVEDO, Renata L.; SANTANA, S.T.; KHOURY, H. J.; SULLASI, H. S. L.; BORGES, F. M.; MARTIN, G.; PESSIS, A-M. 2011. "Datação por termoluminescência de fogueira pré-histórica do sítio arqueológico Baixa do Umbuzeiro (RN)". Revista Brasileira de Pesquisa e Desenvolvimento. Rio de Janeiro: CNEN, v. 13, 116-121.

BORGES, Fábio Mafra. 2010, Os Sítios Arqueológicos Furna do Umbuzeiro e Baixa do Umbuzeiro: caracterização de um padrão de assentamento na área arqueológica do SeridóCarnaúba dos Dantas-RN, Brasil. Tese de Doutorado, Programa de Pós-Graduação em Arqueologia, Universidade Federal de Pernambuco. Recife.

BRITO, Francisco de Paula. 2011. Análise de gravuras rupestres Pré-históricas das bacias hidrográficas do Espinharas/Sabugi/Quipauá- Barra Nova no Seridó Ocidental-RN. Dissertação de Mestrado, Programa de Pós-Graduação em Arqueologia, Universidade Federal de Pernambuco, Recife.

CASTRO, Viviane. M. C. de. 2009. Marcadores de identidades coletivas no contexto funerário pré-histórico no Nordeste do Brasil. Tese de Doutorado, Universidade Federal de Pernambuco, Recife.

CHAGAS JUNIOR, José N. 2017. Arqueologia espacial no Seridó Potiguar: análise e interpretação arqueológica do território na bacia hidrográfica do rio Carnaúba. Dissertação de Mestrado, Programa de Pós-Graduação de Arqueologia, Universidade Federal de Pernambuco, Recife.

DANTAS, José de Azevêdo. 1994. Indícios de uma Civilização Antiquíssima. (Biblioteca Paraibana, v. XI). João Pessoa: A União/Governo do Estado da Paraíba/Secretaria de Educação e Cultura/Fundação Casa de José Américo/Instituto Histórico e Geográfico da Paraíba.

FARIAS, Allysson Allan de. 2013. Diagênese óssea em ambiente semiárido Brasileiro: modelagem e experimentações com sedimentos do sítio Pedra do Alexandre. Dissertação 
de Mestrado, Programa de Pós-Graduação em Arqueologia, Universidade Federal de Perambuco Recife.

FONTES, Mauro Alexandre Farias. 2003. A Cerâmica Pré-história da área arqueológica do do Seridó-RN. Dissertação de Mestrado, Programa de Pós-Graduação em História, Universidade Federal de Pernambuco, Recife.

GOLDMEIER, V.A. 1989. “Geomorfologia de alguns sítios pré-históricos do Seridó-RN". Clio- Série Arqueológica, v.5, 33-40.

GUIDON, Niède. ; BUCO, C. A. 2006. "Zone 3: Brésil - Nordeste - Etats du Piauí, Pernambuco, Rio Grande do Norte et Paraiba". In: Icomos - World Heritage Convention (Org.). Rock Art of Latin America \& The Caribbean. Paris: ICOMOS, 122-137.

LAROCHE, Armand François Gaston. 1988. “Aspecto da cerâmica pré-histórica do Rio Grande do Norte". In: Cerâmica. São Paulo: Órgão Oficial da Associação Brasileira de Cerâmica, a.34, v.34 (219), 27-28.

. 1980. "Contribuições por datações do C-14 às pesquisas arqueológicas nordestinas (Pernambuco e Rio Grande do Norte até 1980)". Suplemento, n.5. Natal: Museu Câmara Cascudo, UFRN.

LUFT, Vlademir. 1989. "Os Restos Alimentares do Sítio Mirador, no Boqueirão de Parelhas, RN”. Clio- Série Arqueológica, v.5, 27-32.

MACEDO H. A. M. de. 1999. A antiguidade do homem no Rio Grande do Norte. A préhistória do espaço norte-riograndense. História do RN n@WEB [On-line]. Disponível em: World Wide Web: <URL: www.seol.com.br/rnnaweb/>. Acesso em: 28 mar. 2020.

MARTIN, Gabriela. 1995-1996. "O cemitério pré-histórico "Pedra do Alexandre", Carnaúba dos Dantas-RN. Clio - Série Arqueológica (UFPE), v. 1 (11), 43-57.

. 1994. "Os rituais funerários na Pré-História do Nordeste". Clio - Série Arqueológica, v. 1, (10), 29-46.

1999. Pré-História do Nordeste do Brasil. Recife: Editora da UFPE. 
1999. "10 mil anos do homem pré-histórico no Rio Grande do Norte". In: MARTIN, Gabriela; CASTRO, Nei Leandro de (coords.). Terra Potiguar: uma viagem pela beleza e pela cultura do Rio Grande do Norte. Barcelona: Bustamante Editores, 24-39.

.2007. "A Arte rupestre do Seridó, na Paraíba e no Rio Grande do Norte". $1^{\circ}$ Seminário Internacional sobre Preservação da Arte Rupestre nos Sítios do Patrimônio Mundial, 2004. FUMDHAMENTOS, n.1, 7-36.

. 1989. “A subtradição Seridó de pintura rupestre pré-histórica do Brasil”. Clio - Série Arqueológica, n.5, 19-26.

. 2010. “A Tradição Nordeste na área arqueológica no Seridó, no Rio Grande do Norte: a Furna do Messias como exemplo de evolução da subtradição Seridó”. Anais do Congresso Internacional de Arte Rupestre. Junho-julho de 2009. FUMDHAMENTOS, v.2, (9), 83-90.

. 1985. "Arte rupestre no Seridó (RN): o sítio Mirador do Boqueirão de Parelhas". Clio - Série Arqueológica, n. 2, 81-95.

. 1982. "Casa Santa: um abrigo com pinturas rupestres do estilo Seridó, no Rio Grande do Norte". Clio - Revista do Curso de Mestrado em História, n.5, 55-78.

. 2003. "Fronteiras estilísticas e culturais na Arte Rupestre do Seridó RN”. Clio - Série Arqueológica, n.16, 14-28.

. 1982. "Indústrias de pontas de projétil no Rio Grande do Norte". Clio Revista do Curso de Mestrado em História, n.5, 81-90.

. Novos dados sobre as pinturas rupestres do Seridó, no Rio Grande do Norte. Clio - Série Arqueológica (UFPE), n.4, 141-147, 1991 (número extraordinário do I Simpósio de Pré-história do Nordeste Brasileiro, Recife, 1987).

. 1984. "O estilo Seridó na arte rupestre do Rio Grande do Norte". Arquivos do Museu de História Natural, v.6-7, Atas da I Reunião Científica da Sociedade de Arqueologia Brasileira (1981-1982), 379-382.

. 1996. "Os sítios rupestres do Seridó, no Rio Grande do Norte (Brasil), no contexto do povoamento da América do Sul". Anais da Conferência Internacional sobre o 
Povoamento das Américas, São Raimundo Nonato, PI, Brasil (1993). FUMDHAMENTOS, n.1, 339-346.

1995. "The Seridó sub-tradition of Rock Painting in Brazil". In: STEINBREING, J. (ed.) Rock Art Studies in America. Oxford: Oxbow Monographs, 129136. 2000. Relatório de Pesquisas Arqueológicas nos Sítios Pedra do Alexandre e Mirador. Recife: UFPE.

MARTIN, Gabriela; BORGES, Fabio Mafra; SENA, Vivian Karla de; SALDANHA, Rafael S. Medeiros; ALMEIDA, Marcellus; NOGUEIRA, Mônica A. Araújo; BARBOSA, Caio C. Araújo. 2008. "Levantamento Arqueológico na Área Arqueológica do Seridó-Rio Grande do Norte- Brasil: Nota Prévia”. Clio - Série Arqueológica, v. 2, (23), 1-18.

MARTIN, Gabriela; MEDEIROS, Elisabeth. 2008. "A Furna do Messias. Um Sítio com pinturas rupestres na área arqueológica do Seridó, no Rio Grande do Norte". Clio - Série Arqueológica, v. 2, (23), 70-86 (CD).

MARTIN, Gabriela; OLIVEIRA, Cláudia; COSTA, Adrienne; MUTZEMBERG, Demétrio; SENA, Vivian Karla de; MENDONÇA, Lucileide; BORGES, Lucila; PESSOA, Gabriela; RIOS, Carlos; VAUS, Marcela. 2006. "Escavação Arqueológica do Sítio Casa Santa, Carnaúba dos Dantas, RN”. (Relatório). Clio - Série Arqueológica, v. 2, (21), 299. 332.

MEDEIROS, Tarcísio. 1985. Proto-história do Rio Grande do Norte. Rio de Janeiro: Ed. Presença/Natal: Fundação José Augusto.

MELlO e ALVIM, M. C. de; UCHÔA, D. P.; SILVA, S. F. S. M. da. 1995-1996. "Osteobiografia da população pré-histórica do abrigo Pedra do Alexandre. Carnaúba dos Dantas, RN”. Clio - Série Arqueológica, v.1, (11), 17-42.

MUTZENBERG, Demétrio da Silva. 2007. Gênese e ocupação Pré-histórica do Sítio Arqueológico Pedra do Alexandre: uma abordagem a partir da caracterização paleoambiental do Vale do Rio Carnaúba-RN. Dissertação de Mestrado, Programa de PósGraduação em Arqueologia. Universidade Federal de Pernambuco, Recife.

NASSER, Nassaro A. de Souza. 1974. "Nova contribuição à arqueologia do Rio Grande do Norte". Programa Nacional de Pesquisas Arquelógicas - PRONAPA, 5. Resultados 
preliminares do Quinto Ano, 1969-1970. (Publicações avulsas, 26). Belém: Museu Paraense Emílio Goeldi. 155-164.

NASSER, Nassaro A. de Souza.; CABRAL, Elizabeth M. 1964. "Informações sobre inscrições rupestres no Rio Grande do Norte". Separata dos Arquivos do Instituto de Arqueologia. Natal: Universidade do Rio Grande do Norte.

NOGUEIRA, Mônica Almeida Araújo. 2011. A Cerâmica Tupinambá na Serra de SantanaRN: o sítio arqueológico Aldeia da Serra de Macaguá I. Dissertação de Mestrado, Programa de Pós-Graduação em Arqueologia, Universidade Federal de Pernambuco, Recife.

QUEIROZ, Albérico N. 2001. Contribution à l'étude archéozoologique des vertebres de cinq sites préhistoriques de trois régions du Brésil. Tese de doutorado, Universidade de Genebra, Suíça.

2002. "Fauna de vertebrados do sítio arqueológico Pedra do Alexandre, Carnaúba dos Dantas, RN: uma abordagem zooarqueológica e tafonômica". Clio - Série Arqueológica, n. 15, 267-282.

QUEIROZ, Albérico N.; CARDOSO, G. M. B. 1995. "Nota prévia sobre a fauna holocênica de vertebrados do Sítio Arqueológico "Pedra do Alexandre", Carnaúba dos Dantas-RN, Brasil”. Clio - Série Arqueológica, v. 1, (11), 137-140.

RAMOS, Ana Catarina Peregrino Torres. 1992. “Aplicação de técnicas de análises físicoquímicas em pigmentos do sítio Pedra do Alexandre- Rio Grande do Norte”. In: SOUZA, A.M. de; GASPAR, M.D.; SEDA, P. (ed.). Anais da $6^{\circ}$ Reunião Científica da Sociedade de Arqueologia Brasileira. Rio de Janeiro: SAB, CNPq/FINEP/UNESA, v.1, 381-388.

. 1995-1996. "Estudo dos pigmentos do sítio Pedra do Alexandre Carnaúba

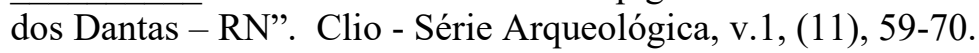

. 1995. O Sítio Pré-Histórico Rupestre Pedra do Alexandre em Carnaúba dos Dantas, RN: estudo dos pigmentos. 1995. Dissertação de Mestrado, Programa de PósGraduação em História, Universidade Federal de Pernambuco, Recife.

. 1994. "O uso de raios-X na identificação de jazidas minerais. O sítio "Pedra do Alexandre” - RN”. Clio - Série Arqueológica, v.1, (10), 21-24. 
SALDANHA, Rafael Sebastian Medeiros. 2014. Riacho das Relíquias: contribuição aos sítios ao Céu Aberto em Carnaúba dos Dantas-RN, Brasil. Dissertação de Mestrado, Programa de Pós-Graduação em Arqueologia, Universidade Federal de Pernambuco, Recife.

SANTOS JÚNIOR, Valdeci dos. 2005. "Registros Rupestres na área Arqueológica de Santana (RN)". Dissertação de Mestrado, Programa de Pós-Graduação em Arqueologia, Universidade Federal de Pernambuco, Recife.

SANTOS, Adelson Antônio da Silva. 1997. Paleopatologia do Sítio Pré-Histórico Pedra do Alexandre- Carnaúba dos Dantas-RN. Brasil: avaliação epistemológica, radiológica e histopatológica. Tese de Doutorado, Programa de Pós-Graduação em História, Universidade Federal de Pernambuco, Recife.

SANTOS, André Luiz Campelo dos. 2016. Estudo da Diagênese Óssea e Experimento de Datação Direta dos Sepultamentos do Sítio Arqueológico Pedra do Alexandre - RN. Dissertação de Mestrado, Programa de Pós-Graduação em História, Universidade Federal de Pernambuco, Recife.

SANTOS, Camila Ferreira dos. 2020. Adornos corporais no Nordeste do Brasil: tecnologia, usos e funções. Dissertação de Mestrado, Programa de Pós-Graduação em Arqueologia, Universidade Federal de Pernambuco, Recife.

SILVA, Adrienne Costa da. 2003. As Representações Zoomórficas na Subtradição Seridó. Dissertação de Mestrado, Programa de Pós-Graduação em Arqueologia, Universidade Federal de Pernambuco, Recife.

SOLARI, Ana; MARTIN, Gabriela; SILVA, Sergio F. S. M. da. 2016(b) “A presença infantil no registro bioarqueológico de Pedra do Alexandre (Carnaúba dos Dantas, RN, Brasil)". Revista FUMDHAMentos, v. 1, (13), 4-30.

SOLARI, Ana; PESSIS, Anne-Marie; MARTIN, Gabriela; SILVA, Sergio F. S. M. da. 2018. "Patologias invisíveis na Bioarqueologia da Infância". Revista de Arqueologia, v. 31, (2), 103-117. 
SOLARI, Ana; SILVA, Sergio F. S. M. da; MARTIN, Gabriela. 2016(a). "Estudos de antropologia dental na população do sítio arqueológico Pedra de Alexandre, Carnaúba dos Dantas, RN (9.000-2.000 AP)". Clio - Série Arqueológica, v.31, (2), 14-58.

SOLARI, Ana; SILVA, Sergio F. S. M.da; OLIVEIRA, Raiane. 2015. "Antropologia dental no sítio arqueológico Pedra do Alexandre, Carnaúba dos Dantas, RN (1.500 a 10.000 A. P)". XVIII Congresso da Sociedade de Arqueologia Brasileira (SAB). Goiania, Brasil (poster).

SULLASI, Henry S. L.; SANTOS, André 1. C.; SILVA SIMÕES, Simone; MARTIN, Gabriela; SILVA, Sergio F. S. M.; FARIAS, Allysson A. 2017. "A Note on Diagenetic Parameters for Bone Remains from Pedra do Alexandre Paleoamerican Site Without Sample Destruction”. Revista FUMDHAmentos, v.19, 74-85.

VALLE, Raoni Bernardo Maranhão. 2003. Gravuras Pré-históricas da área arqueológica do do Seridó Potiguar/Paraibano: um estudo técnico e cenográfico. Dissertação de Mestrado, Programa de Pós-Graduação em História, Universidade Federal de Pernambuco, Recife.

VIDAL, Irma A. 2002. "Projeto arqueológico do Seridó: Escavação no Sítio Pedra do Chinelo, Parelhas, Rio Grande do Norte. Primeiros resultados". Clio - Série Arqueológica, v. $1,(15), 157-169$. 